\title{
Crude oil exploration in Africa: socio-economic implications, environmental impacts, and mitigation strategies
}

\author{
Adedapo O. Adeola ${ }^{1}\left(\right.$ ) Adedibu S. Akingboye $\mathrm{A}^{2,3} \cdot$ Odunayo T. Ore $^{4}\left(\mathbb{C} \cdot\right.$ Oladotun A. Oluwajana $^{2}$. \\ Adetola H. Adewole ${ }^{4}$. David B. Olawade ${ }^{5}$. Abimbola C. Ogunyele ${ }^{6}$
}

Accepted: 30 July 2021 / Published online: 12 August 2021

(c) The Author(s), under exclusive licence to Springer Science+Business Media, LLC, part of Springer Nature 2021

\begin{abstract}
Crude oil exploration is a source of significant revenue in Africa via trade and investment since its discovery in the mid-19th Century. Crude oil has bolstered the continent's economy and improved the wellbeing of the citizenry. Historically, Africa has suffered from conflicts due to uneven redistribution of crude oil revenue and severe environmental pollution. Advancements in geophysical survey techniques, such as magnetic and gravity methods, to seismic methods, have made the commercial exploration of crude oil possible for some other countries in Africa apart from Nigeria, Angola, Algeria, Libya, and Egypt. The occurrence of organic-rich, oil-prone Type I, II, and mixed II/III kerogens in sedimentary basins and entrapment within reservoir rocks with intrinsic petrophysical properties are majorly responsible for the large deposits of hydrocarbon in Africa. The unethical practices by some multinational oil corporations have resulted in social movements against them by host communities and human rights groups. The unscrupulous diversion of public funds, award of oil blocks, and production rights to certain individuals have impaired economic growth in Africa. The over-dependence on crude oil revenues has caused the economic recession in oil-producing countries due to plummeting oil prices and global pandemic. Most host communities of crude oil deposits suffer from a lack of infrastructure, arable soils, clean water, and their functioning capabilities are violated by crude oil exploratory activities, without adequate compensations and remedial actions taken by oil companies and the government. Thus, this review examines crude oil exploration in Africa and provides insight into the environmental and socio-economic implications of crude oil exploration in Africa. Furthermore, this report highlights some recommendations that may ensure ethical and sustainable practices toward minimizing negative impacts and improving the quality of life in affected communities.
\end{abstract}

Keywords Crude oil $\cdot$ Exploration technique $\cdot$ Environmental pollution $\cdot$ Socio-economic impact $\cdot$ Africa

Adedapo O. Adeola

adedapo.adeola@aaua.edu.ng

$\square$ Odunayo T. Ore

oreodunayo@yahoo.com

1 Department of Chemical Sciences, Adekunle Ajasin University, 001 Akungba-Akoko, Ondo State, Nigeria

2 Department of Earth Sciences, Adekunle Ajasin University, 001 Akungba-Akoko, Ondo State, Nigeria

3 Geophysics Section, School of Physics, Universiti Sains Malaysia, 11800 Penang, Malaysia

4 Department of Chemistry, Obafemi Awolowo University, Ile-Ife 220005, Nigeria

5 Department of Environmental Health Sciences, University of Ibadan, Ibadan, Nigeria

6 Department of Earth and Environmental Sciences, University of Pavia, Via Ferrata 1, 27100 Pavia, Italy

\section{Introduction}

The discovery and exploration of natural resources in any country have several socio-economic and environmental implications on the citizenry (Olujimi et al. 2011; Sojinu and Ejeromedoghene 2019; Faria 2020). The African continent accounts for five among the top thirty oil-producing nations in the world (Steyn 2009; Anyanwu et al. 2010; Akpata et al. 2013). The five countries are Nigeria, Angola, Algeria, Libya, and Egypt. In 2019, the aforementioned countries accounted for about 8 million barrels per day, which was almost $10 \%$ of global output (Graham and Ovadia 2019). The continent is endowed with vast deposits of crude oil reserves. In its original state, crude oil has little or no practical application and/or economic value (Dincer and Rosen 
2013). Therefore, the need arises for the conversion of the unprocessed crude into more valuable products.

Africa currently produces about $7 \%$ of the world's gas from a range of basins, including intracratonic sags, epicratonic embayments, and basins that form part of the rift-drift sequence caused by the post-Triassic break up of Pangaea (Selley and van der Spuy 2016). Over 2400 hydrocarbon deposits have been discovered in Africa, 700 of them were large enough for significant exploration (Hemstel 2003; EIA 2017). Petroleum occurs throughout the stratigraphic column from late to recent Archaean (Selley and van der Spuy 2016). Oil production is concentrated in North and West Africa, which holds seven of OPEC's 14 members, producing about $7 \mathrm{~mm}$ bpd; however, minimal production has been recorded outside the North and West Africa (Nyemah 2011). There are two main geographical concentrations of hydrocarbon fields in Africa, namely; (1) West African coastal seaboard between the Niger Delta and the Congo and Cuanza basins and (2) North African basins (from Algeria, across Tunisia, Libya, and Egypt); other producing basins include, the Senegal basin, the Muglad basin in Sudan, and Quteniqua basin, offshore South Africa (Hemstel 2003; Ekweozor 2004).

Natural resources serve as a strong economic base for sustainable development in many African countries (Hachay 2017). The exploration of crude oil in several African countries has brought foreign earnings into those countries, which in turn should improve the living conditions of the population if properly harnessed and managed. Notwithstanding the cost of natural resources management in Africa is high due to lack of infrastructures, poor education, and over-dependence on foreign experts, managerial incompetence, and corruption which has disproportionately affected and hampered the economic growth and development of most African countries (Kalu and Ott 2019).

Severe environmental hazards have been attributed to crude oil exploration and processing in Africa, mostly arising from the discharge of wastes, including drilling fluids, atmospheric emissions, oily drill cuttings, oil spills, gas flares, well treatment fluids, and deck drainage, etc. (Beyer et al. 2020; Vargas et al. 2020). Noise, atmospheric, and marine pollution arises from onshore and offshore operations of oil rigs, distillation plants, tank farms, and vehicular emissions; which negatively impact water and air quality (Pathak and Mandalia 2012; Jiang et al. 2020). Besides, trace elements are introduced into surface waters from deep aquifers, as a result of the exploration processes, and many of these chemicals, such as cadmium, arsenic, mercury, copper, zinc, and lead, etc., are toxic to aquatic animals as well as humans (Ore and Adeola 2021).

There is the rarity of comprehensive literature overview of the significance and impact of crude oil exploration in Africa, which is essential for scientific awareness and policymaking toward mitigation of existing challenges peculiar to the African continent. This comprehensive review, therefore, provides useful insights into the occurrence, relative abundance, and exploration technologies of crude oil in Africa, as well as the socio-economic and environmental impacts of crude oil exploration and processing in Africa. This report also highlights existing and emerging remediation approaches suitable for oil/hydrocarbon-based pollution. The scope of the literature considered in this study was published articles, thesis, and books from reputable scientific journals and university repositories. Table 1 presents the ranking of oil-producing countries in Africa according to World Bank, while Table 2 presents the summary of remediation approaches with recent references. A systematic approach was adopted in the arrangement of relevant sections of this review to ensure clarity and provide suitable reference points for researchers.

\section{Historical occurrence of fossil fuels in Africa}

The presence of viable source rock is an important factor governing the natural formation or occurrence of hydrocarbons (Dahl et al. 1994). In the past few decades, interest in the information on earth's lithospheric (crust and upper mantle) structures has steadily grown to develop knowledge on the deeply submerged sediments, which are the main sources for replenishing crude oil of the twenty-first century and prospects for its abundance in oil-rich areas and new areas (Hachay 2017). The oil and gas sectors play a significant role in the economy of the continent. Most developing countries rich in petroleum resources depend on its sales for revenue and economic development (Graham and Ovadia 2019). The African continent is endowed with Earth's minerals,

Table 1 World bank ranking of major oil-producing countries in the Africa with regard to HDI indices and production capacity as of 2015 ( Source: World Development Index)

\begin{tabular}{llll}
\hline HDI ranking & Country & $\begin{array}{l}\text { Oil production } \\
(\mathrm{mbpd})\end{array}$ & Membership \\
\hline 83 & Algeria & 1348361 & OPEC \\
102 & Libya & 384686 & OPEC \\
111 & Egypt & 494325 & NON-OPEC \\
109 & Gabon & 210820 & OPEC \\
135 & Equatorial guinea & 227000 & OPEC \\
152 & Nigeria & 1999885 & OPEC \\
150 & Angola & 1348361 & OPEC \\
167 & Sudan & 255000 & NON-OPEC \\
176 & Congo & 308363 & NON-OPEC \\
186 & Chad & 110156 & NON-OPEC \\
\hline
\end{tabular}

HDI human development indices, mbpd million barrels per day, $O P E C$ organization of the petroleum exporting countries 
Table 2 Summary of recent remediation approaches for crude oil/hydrocarbon removal for polluted environment

\begin{tabular}{|c|c|c|c|c|c|}
\hline Remediating agent & Process involved & Target pollutant & Efficiency & Contact time & References \\
\hline $\begin{array}{l}\mathrm{Ti}_{3} \mathrm{C}_{2} \mathrm{~T}_{\mathrm{X}} \text { MXene based } \\
\text { sponge }\end{array}$ & Sorption & Crude oil & 40 Times its weight & $20 \mathrm{~min}$ & Gong et al. (2020) \\
\hline $\begin{array}{l}\text { Graphene oxide-mela- } \\
\text { mine sponge }\end{array}$ & Sorption & Crude oil & 95 Times its weight & $12 \min$ & Wang et al. (2020) \\
\hline $\begin{array}{l}\text { Magnetic graphene oxide } \\
\text { composites }\end{array}$ & Demulsification & Crude oil & $98.53 \%$ & - & Wong et al. (2020) \\
\hline $\begin{array}{l}\text { Wood sawdust-coated } \\
\text { magnetite nanoparticles } \\
\text { functionalized with } \\
\text { stearic acid }\end{array}$ & Sorption & Crude oil & - & - & Soliman et al. (2020) \\
\hline $\begin{array}{l}\text { Sawdust functionalized } \\
\text { with Iron oxide nano- } \\
\text { particles }\end{array}$ & Sorption & Crude oil & 47 Times its weight & - & Kamgar et al. (2020) \\
\hline $\begin{array}{l}\text { Zeolitic imidazole frame- } \\
\text { work coated on carbon } \\
\text { fiber }\end{array}$ & Sorption & Crude oil hydrocarbons & 24 Times its weight & - & Shahmirzaee et al. (2020) \\
\hline $\begin{array}{l}\text { Activated carbon and } \\
\text { diatomite }\end{array}$ & Sorption & Crude oil & & & Vasilyevaet al. (2020) \\
\hline Rhizophora mangle & Phytoremediation & PAHs in crude oil & $60.76 \%$ & 90 days & Verâne et al. (2020) \\
\hline Lemna paucicostata & Degradation & Hydrocarbons & $97.74 \%$ & 120 days & Ekperusi et al. (2020) \\
\hline $\begin{array}{l}\text { Legumes (Rhizobium } \\
\text { leguminosarum } \\
\text { BIHIB1217 and Rhizo- } \\
\text { bium leguminosarum } \\
\text { N871) }\end{array}$ & Phytoremediation & Crude oil & - & - & $\begin{array}{l}\text { Enibukun and Boboye } \\
\text { (2020) }\end{array}$ \\
\hline Vetiveria zizanioides & Degradation & $\begin{array}{l}\text { Total petroleum hydro- } \\
\text { carbons }\end{array}$ & $47 \%$ & 120 days & Kiamarsi et al. (2020) \\
\hline $\begin{array}{l}\text { Solid inoculants of LZ-2 } \\
\text { bacteria }\end{array}$ & Biodegradation & Crude oil & $\begin{array}{l}44.2 \% \text { of total alkanes } \\
\text { and } 21.6 \% \text { of cyclic } \\
\text { aromatic hydrocarbons }\end{array}$ & 30 days & Li et al. (2021) \\
\hline $\begin{array}{l}\text { Rhodococcus rho- } \\
\text { dochrous and Nocardia } \\
\text { farcinia }\end{array}$ & Biodegradation & Crude oil hydrocarbons & - & - & Rodrigues et al. (2020) \\
\hline $\begin{array}{l}\text { Exiguobacterium sp. } \\
\text { A0-11 }\end{array}$ & Biodegradation & Crude oil & $75 \%$ & 100 days & Muangchinda et al. (2020) \\
\hline $\begin{array}{l}\text { Rhodococcus sp. Moj- } \\
\quad 3449\end{array}$ & Biodegradation & Long chain n-alkanes & $44.26 \% \mathrm{w} / \mathrm{v}$ & - & - \\
\hline $\begin{array}{l}\text { Rhamnolipids produced } \\
\text { from Pseudomonas aer- } \\
\text { uginosa } \text { PTCC1340 }\end{array}$ & - & Heavy metals in crude oil & - & - & Kholghi et al. (2020) \\
\hline $\begin{array}{l}\text { Biosurfactant produced } \\
\text { from Bacillus subtilis } \\
\text { strain Al-Dhabi-130 }\end{array}$ & Biodegradation & & & & Al-Dhabi et al. (2020) \\
\hline $\begin{array}{l}\text { Staphylococcus sp. } \\
\text { CO100 strain with its } \\
\text { biosurfactant }\end{array}$ & Biodegradation & $\begin{array}{l}\text { Crude oil aliphatic hydro- } \\
\text { carbons }\end{array}$ & $72 \%$ & - & - \\
\hline Bacillus megaterium & Biodegradation & Crude oil & - & - & Alnuaimi et al. (2020) \\
\hline $\begin{array}{l}\text { Pseudomonas putida } \\
\text { immobilized on coco- } \\
\text { nut coir pith }\end{array}$ & Biodegradation & $\begin{array}{l}\text { Total petroleum hydro- } \\
\text { carbons }\end{array}$ & - & - & Annie et al. (2020) \\
\hline Pseudomonas aeruginosa & Biodegradation & Crude oil & $63.38 \%$ & 60 days & Deivakumari et al. (2020) \\
\hline Bacillus licheniformis & Biodegradation & Heavy crude oil & $15-66 \%$ & 14 days & $\begin{array}{l}\text { Khanpour-Alikelayeh et al. } \\
(2020)\end{array}$ \\
\hline Pyrolytic treatment & Volatilization & Light oil & - & - & Kang et al. (2020) \\
\hline $\begin{array}{l}\text { Rhamnolipid used in con- } \\
\text { junction with biochar }\end{array}$ & & & & - & Wei et al. (2020a) \\
\hline
\end{tabular}


Table 2 (continued)

\begin{tabular}{llllll}
\hline Remediating agent & Process involved & Target pollutant & Efficiency & Contact time & References \\
\hline $\begin{array}{l}\text { Biochar used in conjunc- } \\
\text { tion with biosurfactants } \\
\text { and nitrogen }\end{array}$ & Adsorption & $\begin{array}{c}\text { Total petroleum hydro- } \\
\text { carbons }\end{array}$ & $80.9 \%$ & - & (Wei et al. 2020b) \\
$\begin{array}{l}\text { Aerosols with cellulose } \\
\text { Organic waste }\end{array}$ & adsorption & Crude oil & - & - & (Paulauskiene et al. 2020) \\
\hline
\end{tabular}

however, comprehensive knowledge of relative abundance via a country-based assessment remains a challenge. The discoveries of new hydrocarbon fields in the continent, continue to provide economic leverage via trade and investment (African Development Bank (AfDB) 2009) and retains Africa on the list of a major exporting region in the world (Graham and Ovadia 2019). For many decades, hydrocarbon is a source of energy and they account for $83 \%$ of the current global consumption (Duissenov 2013).

The first commercial quantities of oil in Africa were found in Oloibiri in Ogbia LGA of Bayelsa State, Niger Delta basin of Nigeria, West Africa in the year 1956, by the Shell D'Arcy (now Shell Petroleum Development Company). In less than 20 years, the region became known for holding some of the world's largest reserves of oil and gas (Steyn 2009; Anyanwu et al. 2010; Akpata et al. 2013). Crude oil exploration began in East Africa in early 1920, beginning with Anglo-American's Dudley Expedition to Abyssinia, and with the major efforts in Uganda and the Eritrean Red Sea where there was extensive shallow drilling around oil seeps. Eastern Africa is the emerging hydrocarbon province of the 21st Century. However, successful exploration was recorded only after several decades of unsuccessful hydrocarbons search. Subsurface Palaeozoic hydrocarbon exploration of the Sahara Desert province of Libya, Algeria, Tunisia, and Morocco in North Africa began in the early 1950s. The exploration was undertaken after the discovery in the 1930s and 1940s, due to the large Palaeozoic basin in the Sahara Desert of North Africa with a potential prospect for hydrocarbons. The first petroleum wildcat exploration drilling took place in Algeria in 1952 and the first discovery was made not until 1953 in non-commercial quantity, but in 1956 major discoveries were achieved (Traut et al. 1998).

Recent oil reserves have increased the importance of this resource in African economies. Five African countries dominate the upstream oil production accounting for $85 \%$ of the continent's oil reserve. These countries are Nigeria, Libya, Algeria, Egypt, and Angola. Other oil-producing countries are Gabon, Congo, Cameroon, Tunisia, Equatorial Guinea, Democratic Republic of Congo, Cote d'Ivoire, and recently, Ghana (low output), while Mozambique and Tanzania have reportedly discovered crude oil (Figs. 1, 2). Nonetheless, exploration has been undertaken in some other African countries, such as Chad, Sudan, Namibia, South Africa, and
Madagascar, but these countries have yet to record success stories (ECOWAS-SWAC/OECD 2007; AfDB 2008, 2009; Anyanwu et al. 2010; Akpata et al. 2013; EIA 2017). Based on the data available in 2019 , Nigeria was the leading oil producer in Africa producing about 101.4 million metric tons in the country. Angola and Algeria followed with 69.1 million and 64.3 million metric tons of oil, respectively (Faria 2020). The occurrence of giant hydrocarbon fields in sedimentary basins of Africa implies propitious convergence of geochemical factors that favored the development of excellent petroleum systems.

\section{Notable hydrocarbon fields in Africa}

Crude oil deposit is found within stratigraphic columns extending from geographically ubiquitous seepages in recent sediments to oil in fluid inclusions in the late Archaean sediments present in the Witwatersrand basin (England et al. 2002).

\subsection{Niger delta basin}

The Niger Delta is located at the southern end of a major series of rifts extending from what is now the Atlantic Ocean to the modern Mediterranean (Selley and van der Spuy 2016) and ranks among the world's most prolific petroleum-producing Paleogene-Neogene deltas that together account for about 5\% of the world's oil and gas (Ajaegwu et al. 2014). The Niger Delta consists of three diachronous facies: the on-delta fluvial Benin Formation, delta front sands and muds of the Agbada formation, and the over-pressured slope muds of the Akata formation. This sediment pile prograded over the deep-water submarine channel and fan sands (Selley and van der Spuy 2016; Ogbe 2020).

The source rocks responsible for the formation of hydrocarbon for the Niger Delta basin have been the subject of controversy. This controversy has arisen because of the difficulty in locating source intervals sufficiently convincing to have given rise to the large volumes of oil trapped, so far, only traces of potential source rocks have been recorded (Bustin 1988). Depending on where you are in the delta, source rocks range in age from middle Eocene to Pliocene and they contain predominantly terrigenous organic matter 


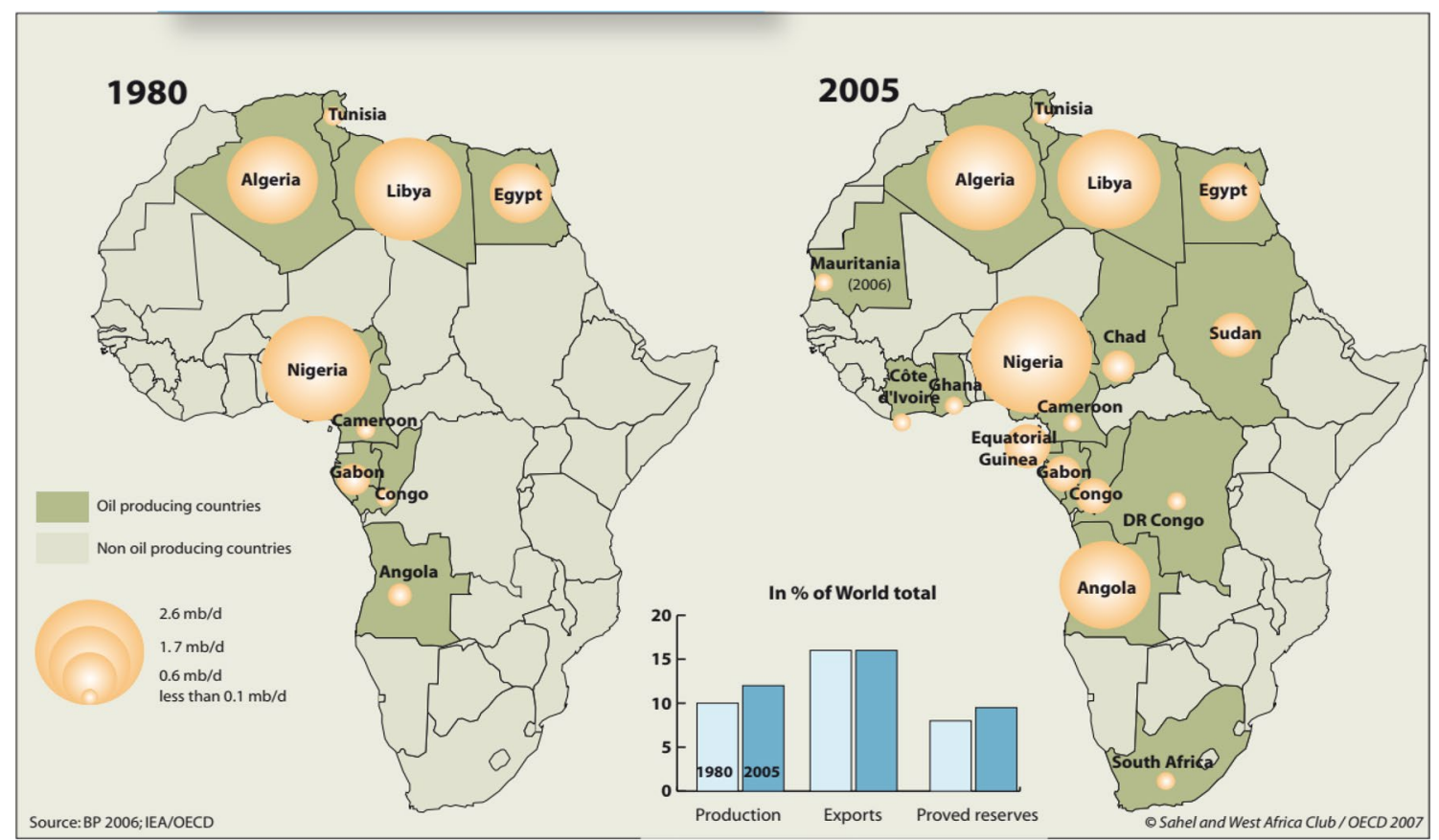

Fig. 1 Maps of Africa showing the evolution of oil production in Africa (ECOWAS-SWAC/OECD 2007)

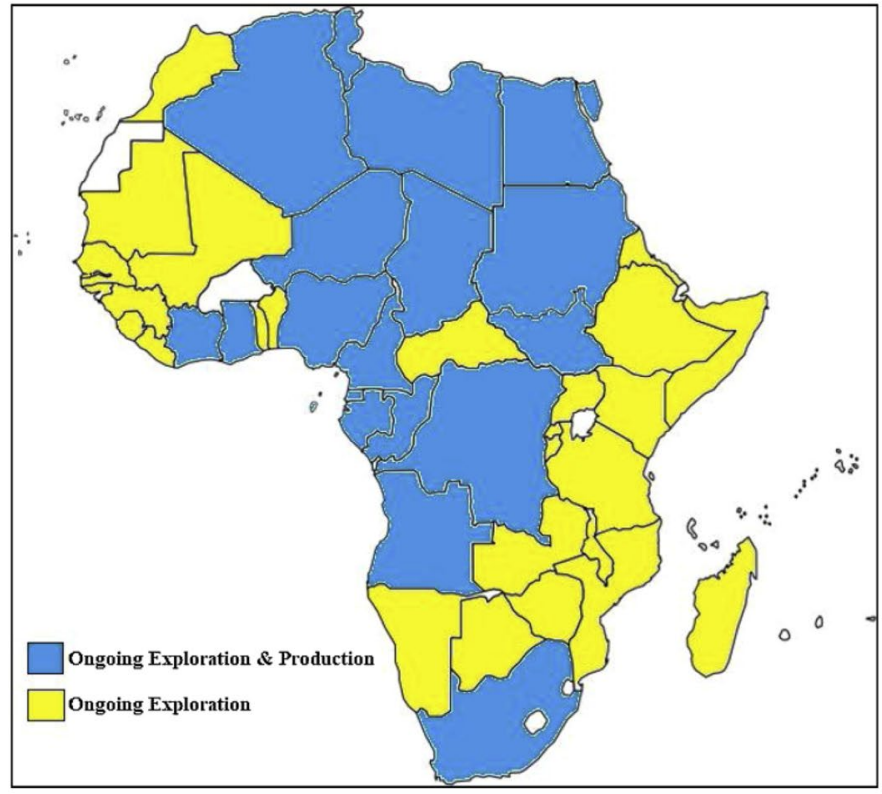

(a)

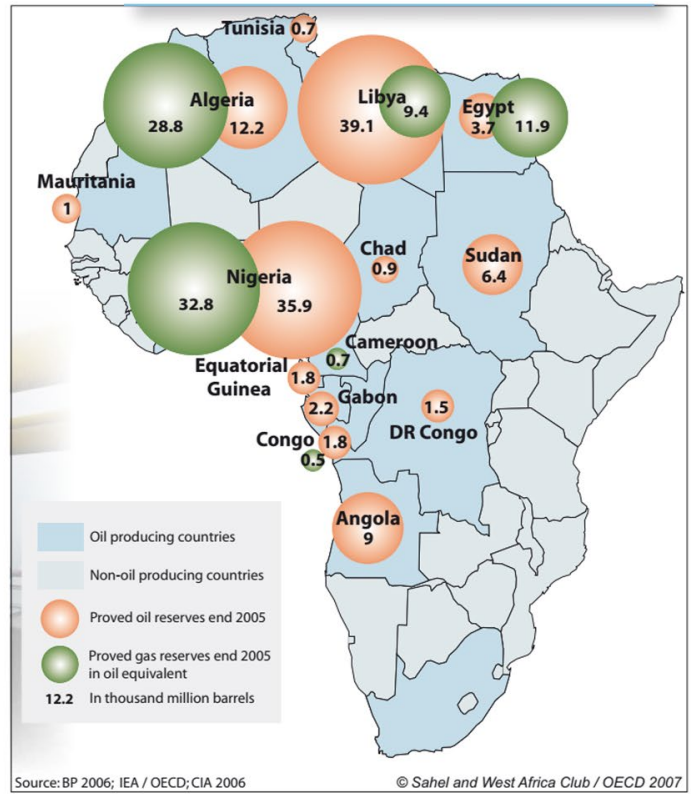

(b)

Fig. 2 Maps of Africa showing a current crude oil exploration (after Graham and Ovadia 2019) and b proven oil and gas reserves (as at the end of 2005) in Africa

(Haack et al. 2000). These source rocks generate light waxy oils or gas. Therefore gas-prone end-member of the organic facies' spectrum was deposited in an anoxic depositional environment in which organic matter was poorly preserved (Haack et al. 2000). Oil-prone organic facies, however, were deposited in sub-toxic depositional environments in which enhanced preservation of terrigenous organic matter was possible (Haack et al. 2000). The differences in source facies undoubtedly result from variation in the composition of 
organic matter components, which contribute to the kerogen of the richer source facies (Bustin 1988; Haack et al. 2000).

Niger Delta basin has five depobelts namely the Northern Delta, Greater Ughelli, Central Swamp, Coastal Swamp, and the offshore depobelts (Fig. 3). Each of the depobelts has source rocks responsible for the formation of hydrocarbon. The Northern Delta depobelt is a significant petroleum province in the Niger delta basin. Oluwajana et al. (2017) explained that Eocene source facies could be responsible for oil discoveries in Northern Delta depobelt. The Eocene source rock has $0.42-1.17 \mathrm{VR}_{0}$, suggesting a thermally immature to mature source rock. The TOC contents of the Upper Oligocene shale facies in the Greater Ughelli depobelt ranges from 1.7 to $31.8 \mathrm{wt} . \%$, indicating good to excellent source rock (Oluwajana 2018a; b). It is assumed that the deeply buried upper Oligocene source facies entered the main oil window during Neogene and may have contributed some hydrocarbon to interbedded Agbada sandstones of the Greater Ughelli depobelt of Niger Delta Basin (Oluwajana 2018a,2018b).

The Miocene source rocks of the Coastal Swamp depobelt are dominated by organic-clean and gas-prone Type III/IV kerogen, with a minor contribution from oil and gas-prone of mixed Type II/III kerogen, would have contributed minimally to the oil deposit of the Niger delta basin (Oluwajana 2019). Late Miocene-Early Pliocene source rock entered the early oil generation window during the Miocene age with a transformation ratio of less than $1 \%$, suggesting that enough hydrocarbons have not been significantly expelled to adjoining reservoirs (Oluwajana, 2018b). Ekweozor (2004) suggested that the Cenomanian-Turonian anoxic sediments entered the oil window just before or during the Santonian tectonism, but the corresponding strata underlying the Niger delta in the deep offshore where the Paleogene-Neogene overburden is considerably thinned down ought to have generated huge amounts of liquid petroleum more recently to contribute to giant oil pools in the Niger delta basin.

\subsection{Congo basin}

The Congo Basin contains the Congo Delta Composite Total Petroleum System, consisting of Lower Cretaceous to Tertiary source and reservoir rocks. The Cuanza-Namibe Assessment Unit is defined in the Cuanza Composite Total Petroleum System (Brownfield and Charpentier, 2006). In the offshore Lower Congo and outer Kwanza Basins of Angola, this syn-rift event produced the lacustrine source rocks of the Bucomazi Formation which is as much as $1500 \mathrm{~m}$ thick (McHargue, 1990). The source rocks in the middle units of the Bucomazi Formation contain Type I kerogens and have TOC as high as $20 \mathrm{wt} . \%$, the source rocks of the lower and upper units of the Bucomazi contain Type I and Type II kerogens and average $2-3$ wt.\% TOC, although some organic-rich claystone locally contains more than 10 wt.\% TOC (Brice et al. 1982; Schoellkopf and Patterson 2000). Hydrocarbon source rocks within the early syn-rift section of the outer Kwanza Basin contain thick, organicrich, lacustrine shales, which have abundant Type I kerogen (Pasley et al. 1998).

In the northern part of the Congo Basin, potential source rocks namely the lacustrine Pointe Noire Marl, and Sialivakou Shale. The lacustrine Pointe Noire Marl contains Type

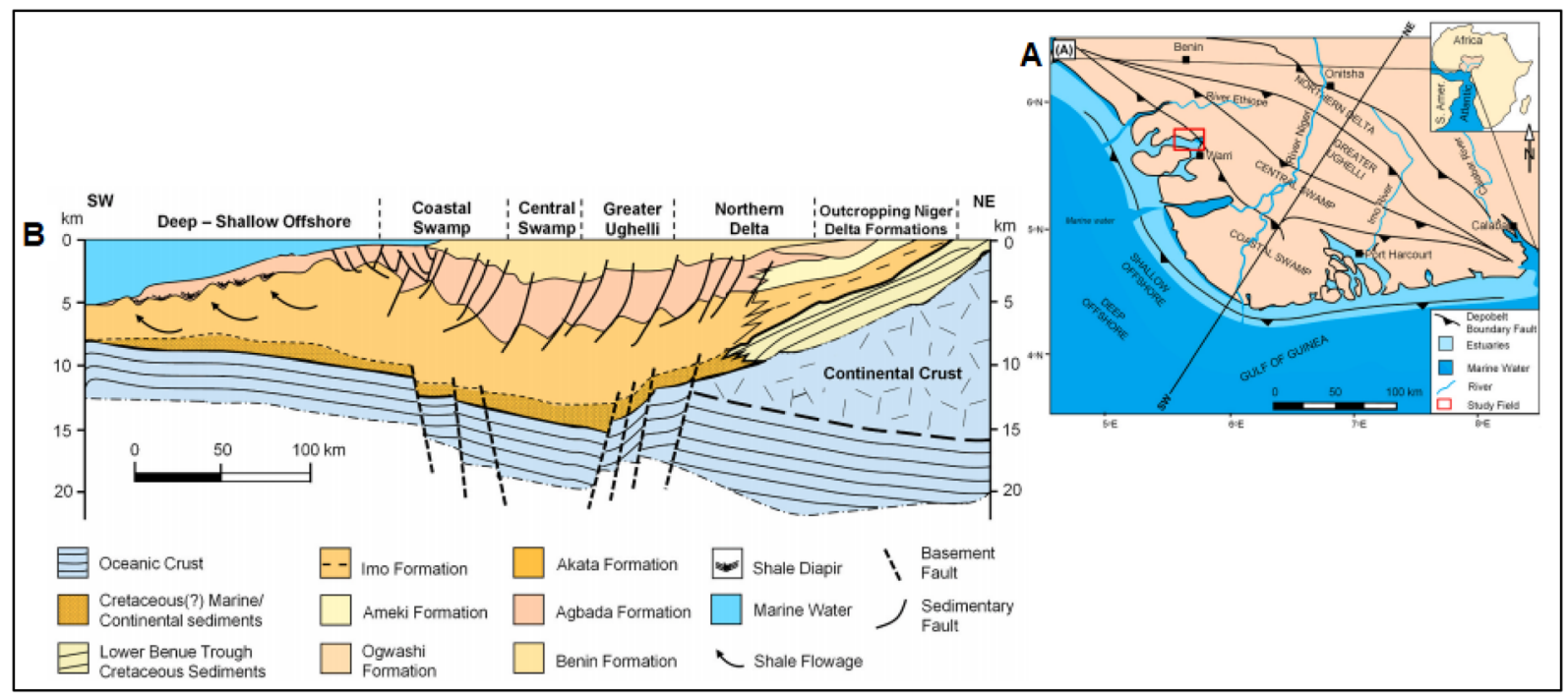

Fig. 3 A Simplified regional geological setting map of the Niger Delta, showing the different depobelt. B Schematic stratigraphic dip section of the Cenozoic Niger Delta Basin shows the position of the various depobelts with the three diachronous lithostratigraphic formations and associated depositional structures (Ogbe 2020) 
I and Type II saprolitic organic matter averaging from 1 to $5 \mathrm{wt} . \%$ TOC; some source rocks contain more than $20 \mathrm{wt} . \%$ TOC (Baudouy and Legorjus 1991). The Sialivakou Shale contains Type II and Type III organic matter and has TOC contents averaging $1 \mathrm{wt} \%$ (Brownfield and Charpentier 2006). In the central and southern Congo Basin, the Paleocene to Eocene source rocks of the Landana Formation consists primarily of deep-water shales with TOC contents as high as 3-5 wt.\%, similar to those of the Iabe Formation (Brownfield and Charpentier 2006). The mid-Oligocene to Miocene Malembo Formation generally has TOC contents of 1-2 wt.\%; the lower and upper parts of the formation contain from 2 to $5 \mathrm{wt} . \%$ TOC in the form of Type II and Type II/III kerogens. The offshore section now contains deep marine source rocks in fault-controlled troughs (Lunde et al. 1992). Offshore marine source rocks with Type II and Type II/III kerogens contain 2-10 wt.\% TOC (Raposo and Inkollu 1998), and the oil compositions in discoveries in the outer Kwanza Basin also suggest a marine source.

In Congo, Angola, and Gabon, petroleum is trapped in Tertiary submarine fan sands, in Cretaceous carbonate reservoirs associated with complex salt tectonics, and in pre-salt lacustrine carbonates and turbidite sands sourced by interfingering non-marine organic-rich shale (Selley and van der Spuy 2016).

\subsection{North African basins}

The Frasnian organic-rich shales have been mapped in parts of Morocco, Algeria, southern Tunisia, western Libya, and the Western Desert of Egypt (Lüning et al. 2003). The Frasnian black shales form an important petroleum source rock in North Africa and account for about $10 \%$ of all Paleozoic-sourced hydrocarbons in North Africa (Fig. 4) (Lüning et al. 2003; Selley and van der Spuy 2016).

Frasnian hot shales are organically the richest and thickest hot shale package developed in eastern Algeria. The hot shales are absent in the southern part of the Ahmet Basin and reach maximum values in the central and eastern parts of Algeria (Lüning et al. 2003). The discovery of paraffinic oil in 1980 in the Adrar area, the west part of the Algerian Sahara within the Sbaa half-graben depression, opens a new oil- and gas-bearing region in Algeria (Baghdadli 1988). The organic content in the Frasnian shales of the Sbaa Basin rarely exceeds $1.2 \%$ and the present-day thermal maturities range between 0.6 and $1.2 \mathrm{R}_{0} \%$, the peak of hydrocarbon generation from the Frasnian organic-rich shales in the Sbaa basin is estimated to have occurred (Lüning et al. 2003). Thermoluminescence indicates the provenance for the Sbaa sands was the crystalline basement Cambrian and Ordovician sections (Mehadi 1990). Gas and wet gas deposits are related to sandstone reservoirs of Cambrian-Ordovician age at depths of 1500-2000 m (4920 to $6562 \mathrm{ft}$ ) (Baghdadli 1988).

The Ghadames Basin is a large intracratonic basin, covering portions of Algeria, Tunisia, and Libya (Echikh 1998). The sedimentary section within the Ghadames (Berkine) ranges from Cambrian to the present and is approximately $7000 \mathrm{~m}(23000 \mathrm{ft})$ thick in the depocenter. The basin has experienced several tectonic events, which have modified its architecture and affected the petroleum systems and hydrocarbon pathways (Aissaoui et al. 2016). The main petroleum systems of the Ghadames (Berkine)/Illizi Basin are represented by the Silurian Tannezuft hot shale source rock with Ordovician Djeffara and Silurian Acacus reservoirs, by Silurian Tannezuft hot shale with Kirchaou reservoirs, and by the Devonian Aouinette Ouinine Formation Member III source rock with Kirchaou reservoirs (Aissaoui et al. 2016). The Frasnian organic-rich shales of the Ghadames (Berkine)/Illizi Basin are termed "Argile Frasnienne Radioactive" in eastern Algeria and, in southern Tunisia, are part of 'term III' (Frasnian) of Aouinet Quenine Formation (Lüning et al. 2003).

The high organic matter content of the Frasnian hot shale in eastern Algeria (up to 14\% of oil-prone type I-II kerogen of the Ghadames Basin) makes it an important petroleum source rock (Lüning et al. 2003). Estimates revealed that the core phase of generating hydrocarbons from the Frasnian hot shales started in Mid-Cretaceous times (Daniels and Emme 1995; Ghenima 1995). The Frasnian shales underwent an initial, minor generative phase in the central depression during the Carboniferous. However, the main generation occurred during the late Jurassic-Cenozoic in the western and central depressions. The Frasnian shales are currently only marginally mature in the eastern part of the basin (Underdown and Redfern 2008). The Lower Silurian Tanezzuft source rock underwent two main phases of hydrocarbon generation. The first phase occurred during the Carboniferous, and the second started during the Cretaceous, generating most hydrocarbons in the eastern (Libyan) basin (Underdown and Redfern 2008).

In the Illizi Basin, organic carbon content is generally less than $6 \mathrm{wt} . \%$. The kerogen is predominantly oil-prone to mixed kerogen facies (Lüning et al. 2003). The Libyan part of the Ghadames (Berkine) Basin has a highly radioactive carbonate-black shale/marl interval. Frasnian paleoenvironments in the Libyan part of the Ghadames Basin ranges between the fully marine outer shelf and marginal marine (Lüning et al. 2003). The organically richest Frasnian shales in the western Desert Basin are reported from the northwestern part of the basin (Lüning et al. 2003) and possess a maximum TOC value of 6.27 wt.\%. The Silurian and Devonian source rocks occur across large parts of the basin and have generated volumes of hydrocarbon (Echikh 1998). 


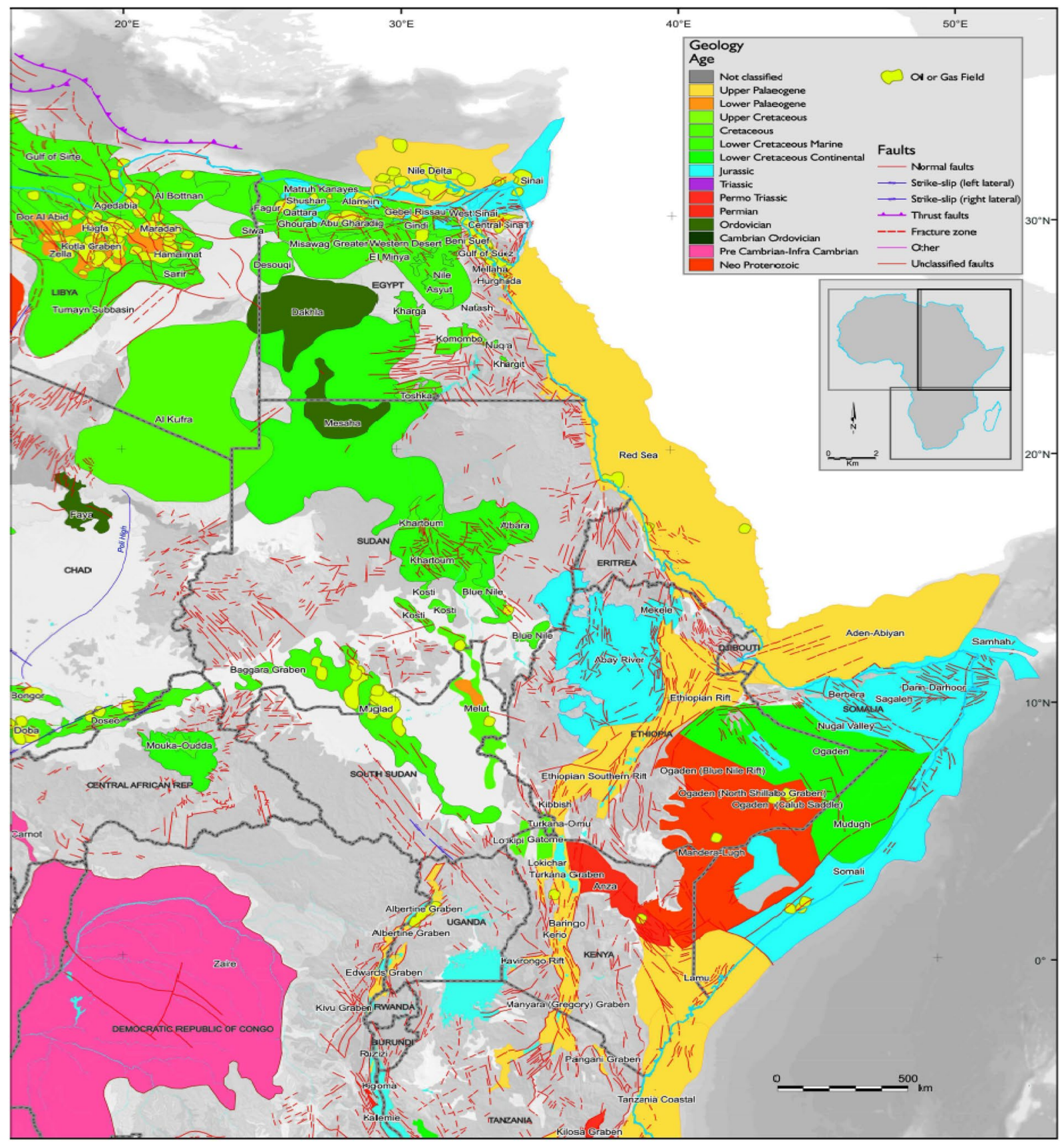

Fig. 4 Map of northeastern Africa showing sedimentary basins and petroleum plays (Selley and van der Spuy 2016)

\section{Crude oil exploration methods and technologies}

The fundamental exploration techniques currently employed remains the same as those employed in the early scientific oil exploration of 1912 in the discovery of Cushing Field in Oklahoma, USA, but modern technology and engineering have greatly improved the performance and safety of crude oil exploration today united nations environmental programme (UNEP 1997). To exploit oil and gas maximally, several exploration methods and technologies, and processing techniques are employed in the oil and gas industries. The oil and gas industry is made of two categories: 'upstream'-the exploration and production sector of the industry; and 'downstream'-the sector which deals with refining and processing of crude oil and gas products, their distribution, and marketing. The exploration and production processes together are referred to as E\&P. The facilities and systems employed in oil and gas industries are broadly defined based on exploration, upstream/downstream, 
midstream, refining, and petrochemical (UNEP 1997; Devold 2013).

The search for hydrocarbon-bearing rock formations involves the desk studies of geological maps to identify major sedimentary basins; use of aerial photography and land-satellite imagery to identify favorable oil landscape formations such as faults or anticlines; and the use of geophysical and geochemical exploration techniques (Assaad 2009; Economides and Nikolaou 2011; Sharma and Chaturvedi 2014; Graham and Ovadia 2019; Karolyté et al. 2020; Murray and Power 2020). To derive detailed information for oil exploration, field geological assessment is done, and this is followed by the use of surface (indirect) and subsurface (direct) geophysical methods that take place before the development of a field is finalized (Telford et al. 1990). Surface and subsurface geophysical methods employ the principles of physics to characterize the earth's subsurface features in order to determine the zone of viable geologic interests. The main surface geophysical methods used in crude oil exploration include potential field methods (gravity and magnetics) and seismic methods (reflection and refraction). The surface geophysical methods determine the density, magnetic, and acoustical properties of a geologic medium. The seismic surveys are the most essential in crude oil exploration. The surveys are carried out in already outlined and delineated location(s) from the other reconnaissance surface geophysical methods. Due to the high amount of money, resources, and logistics required for seismic surveys, a high level of expertise is required starting from desk studies to reconnaissance surveys and seismic field (onshore and offshore) surveys, as well as their data processing and interpretation. The other geophysical methods used in crude oil exploration involve the subsurface or direct geophysical methods employing well drilling techniques (vertical, horizontal, and deviated wells) and geophysical well logging. The choice of method(s) selected depends on the type of desired geologic information, the nature of the subsurface materials, and the cultural interference (Telford et al. 1990; Assaad 2009). The integration of all these geophysical methods provides more details about the subsurface geology favorable for hydrocarbon exploration compared to relying solely on one or two methods.

\subsection{Surface geophysical crude oil exploration methods}

\subsubsection{Magnetic and gravity methods in crude oil exploration}

Magnetic and gravity methods are used only in primary (reconnaissance) surveys where little is known of the subsurface geology and/or the thickness of sediments of potential interest (Telford et al. 1990; Parasnis 1993; Kearey et al.
2002; Assaad 2009). A magnetic survey carried out either on land (often known as ground magnetics), or in the air (known as aero- or airborne-magnetics), or at sea (referred to as shipborne/marine magnetics) employing an instrument known as "magnetometer" is primarily used to explore for oil and minerals. Magnetic exploration is based on the fact that the earth acts as a magnet (with dipoles) caused by magnetic minerals - mainly magnetite and pyrrhotite in the earth's crustal formations. The positioning of any magnetic material in an external field will bring about an inducement of magnetic poles on its surface. The strength of the induced magnetization is directly proportional to the strength of the applied field; this is as a result of the one-directional placement of the applied field and induced magnetization. The magnetic inclination or that of the earth's field is the measuring parameter for the location of an area relative to the magnetic poles (Assaad 2009; Clark 2014). The aeromagnetic survey developed primarily for detecting submerged submarines during the world war has since become considerably used and recorded several successful results in crude oil and mineral exploration. The numerous advantages of this method over that of ground survey include coverage of vast areas (regional reconnaissance survey) at a shorter period; coverage of irregular, difficult, or inaccessible terrains; removal of erratic near-surface features causing a nuisance in groundwork; and easier interpretation of the data due to its smoother nature. The shipborne or marine magnetic survey, on the other hand, employing ship provides no additional advantage and incurs considerable cost increase, except when integrated with other surfaces geophysical oil exploration methods. It is mainly applicable in large-scale oceanographic surveying related to crude oil search (Telford et al. 1990; Kearey et al. 2002).

The gravity method is based on the variations in lateral changes in the density of earth materials in the vicinity of the measurements. Gravity survey either on the ground, or in the air, or at sea employs an instrument called "gravimeter or gravity meter", which are of two types-stable and unstable gravimeters. Usually, the unstable gravimeters known for their high precisions and accuracy are employed in crude oil search. The earth's gravitational attraction at a particular location is dependent on the density of subsurface geologic formations due to the characteristic range of rocks' densities which may differ from one laterally adjacent rock to another rock. The variations may be attributed to changes in rock porosity, degree of fluid saturation, fractures, and varying thickness of sediments consolidation or overburden cover. Besides the field precautions to achieve accurate results, some corrections, such as drift, latitude, elevation (free-air, Bouguer and terrain corrections), tidal, and Eotvos (when vehicular motion is involved), are applied to the gravity dataset to remove variations associated with instrument, latitude, elevation, the topography of surrounding terrain, earth tides, 
and density variation in the subsurface (Telford et al. 1990; Parasnis 1993; Kearey et al. 2002). The results after the values of Bouguer and free-air anomalies have been obtained are then analyzed qualitatively or quantitatively to map deep crustal structures hosting the hydrocarbon and controlling their migration. In oil exploration, aeromagnetic along with surface gravity is done as a preliminary survey before the seismic survey to establish appropriate depth, topography, and the character of the bedrock's architecture. The magnetic methods also have important corrections that must be applied to annul the effects of variations, such as secular and diurnal variations, and magnetic storms.

\subsection{Seismic crude oil exploration survey-seismic refraction and reflection methods}

Seismic refers to vibrations of the earth from either earthquake or artificially generated elastic sound waves (or seismic waves) that penetrate the earth's subsurface measuring at the frequency range of about $10-100 \mathrm{~Hz}$. The depths investigated for a sound wave to propagate into the earth and return to the surface were as much as tens of kilometers. The elastic waves generated travel at different velocities and are being refracted or reflected at geologic boundaries with contrasting acoustic impedance. Seismic data acquisition employs shot points at different survey lines at the earth's surface to obtain high-quality seismic data. The energy required for oil exploration is generated through the use of explosives (TNT or dynamite) or vibroseis (both may be used onshore), and airguns (offshore). The generated sound waves are detected by channel of geophones (for the onshore survey) or hydrophones (for the offshore survey); these are electrochemical transducers that convert ground motion into an electrical analog signal (Telford et al. 1990; Kearey et al. 2002; Assaad 2009; Akingboye and Ogunyele 2019). The seismic signals received from the surveyed site are summed automatically by the seismograph, canceling out the surface waves and other extraneous impulses, and the primary reflected wave is prominently displayed on the cathode ray tube. Seismic methods can reveal the subsurface geological conditions and map undulating interfaces of very deep depth extents (Economides and Nikolaou 2011; Akingboye and Ogunyele 2019).

The seismic refraction method was the earliest and principal method employed in the search for hydrocarbon-bearing structures. Nowadays, hydrocarbon exploration depends mostly on a variety of seismic reflection methods and their two-, three- and four-dimensional (2D, 3D, and 4D) modeling techniques. Nevertheless, seismic refraction is occasionally used for resolving complex structures associated with hydrocarbon exploration. The seismic refraction method measures the travel times of seismic waves refracted at the interfaces between subsurface layers of different velocities
(Carpenter et al. 2003; Cramer and Hiltunen 2004; Hiltunen and Cramer 2006; Economides and Nikolaou 2011; Akingboye and Ogunyele 2019). In seismic reflection hydrocarbon exploration, the reflected seismic waves at different subsurface interfaces which are recorded as travel times in the form of seismic traces are processed using several forms of data processing techniques to remove surface waves (ground rolls), heat waves, and some refracted waves when they constitute noise to the mapping of hydrocarbon geologic structures, such as stratigraphic and structural traps. Besides, the reflection times on seismic traces have to be corrected for time differences caused by near-surface irregularities, which have the effect of shifting reflection events on adjacent traces out of their true time relationships. These data processing techniques include shot gather, common mid-point (CMP) gather or common depth point (CDP) as an older term used by seismic industries, and normal move out (NMO) for correcting each trace to the equivalent of a zero-offset trace, among others (Telford et al. 1990; Quigley 2006; Assaad 2009).

The interpretation of seismic results involves the extraction of all available information from the seismic data, such as geologic structures, rock stratigraphy/layering, reservoir properties (e.g., porosity), and reservoir fluid changes in space and time (in 4D seismic interpretation) (King 2009; Tsvankin et al. 2010; Economides and Nikolaou 2011; Gao 2011). 3D seismic technology results can perform reservoir characterization of unparalleled quality with essential effects on exploration finding rates and volumes of roughly order of magnitude, oil and gas recovery, reserves replacement, reduction in the risk of drilling dry holes or marginal wells, etc. As the discoveries of crude oil deposits are increasingly found in challenging locations, the use of 3D seismic imaging technology remains relevant for both technical and economic reasons (Nestvold 1993; Weimer and Davis 1996).

In recent years, the emerging computational efficiency and cost reduction technologies have made it profitable to conduct multiple 3D seismic surveys in the same field over time; hence, this kind of survey is known as time-lapse or 4D seismic (Parker et al. 2003). The time-lapse or 4D seismic survey is carried out by repeated shooting of 3D (and often 3C) surveys over a producing field at regular intervals (Kearey et al. 2002). 4D seismic technology depends on comparing data from seismic experiments separated by a few years as the reservoir produces. Through this, values of several variables associated with the reservoir, for instance, fluid location and saturation (water, oil, and gas), pressure, and temperature, can be inferred and used in reservoir management plans, such as well and facilities placement or production optimization. This is particularly important for offshore oil applications, where the drilling and production cost of oil is high, and where the vast majority of 4D seismic surveys are employed (Iyer et al. 1998; Saputelli 
et al. 2005). Today, most development in seismic technology is mainly focused on interpretation for efficient synthesis combining elaborate numerical results in order to resolve any complexity associated with oil exploration (Economides and Nikolaou 2011).

\subsection{Subsurface geophysical oil exploration methods: drilling and geophysical well-logging}

The subsurface geophysical crude oil exploration methods are employed for the purpose of having direct contact with the subsurface lithologies, and formation reservoir identified from the interpretation of the surface geophysical crude oil exploration methods and subsurface structural models, and to allow the wellbore to be logged immediately after drilling (open well) or after the well is cased using geophysical logging tools. The logging tools are used to determine the formation temperature, degree of water, and hydrocarbon saturation, and are useful in the estimation of the optimum yield of hydrocarbon. All derived information from these methods prepares the wellbore for development to exploit the hydrocarbon for use.

\subsection{Crude oil drilling techniques}

The crude oil drilling techniques are used when promising geological structures hosting hydrocarbon of economic quantity are identified either onshore or offshore. The purpose of drilling in crude oil exploration is enormous, and the wells drilled serve different purposes. Some of these wells are drilling to verify the presence or absence of a hydrocarbon reservoir and to quantify the reserves; this type of drilling is known as the exploratory or wildcat well. It also determines the thickness and internal pressure of a reservoir to be developed for exploitation. Furthermore, the appraisal well drilled after the success of exploratory drilling is used to determine the economic viability of the hydrocarbon reservoir for development, size, and nature of the reservoir, the number of confirming or appraisal wells required in some cases, and whether any further seismic work is needed. This is followed by the development and production well to produce oil and gas from the reservoir through formation pressure, artificial lift, and probably employing the use of hydraulic fracturing, an advanced recovery technique, for optimum hydrocarbon recovery from tight reservoirs (Assaad 2009; Steyn 2009; Ofwona 2010).

Hydrocarbon wells are drilled using any of the drilling techniques which include percussion or cable drilling, rotary drilling, dual-wall reverse-circulation drilling, electrodrilling, and directional drilling (Funnell 2016). Traditionally, oil and gas production is accomplished using vertical well drilling; however, the directional drilling techniques of hydrocarbon wells, namely the horizontal-, sidetrack-, and deviated-drilling, is intentionally employed in the deviation drilling of a wellbore from the vertical at an angle to reach different parts of the formation for optimum oil and gas recovery. The horizontal well drilling is a type of drilling where the hydrocarbon well is drilled at an angle of more than 80 degrees from the vertical to retrieve oil and gas in situations in which the shape of the reservoir is abnormal or difficult to access, and it allows the access to the subsurface reservoir that may not be accessible from directly above. Today, modern wells are drilled with large horizontal offsets to reach different parts of the structure and achieve higher production (Economides and Nikolaou 2011; Devold 2013).

\subsection{Geophysical well (borehole) logging methods of oil exploration}

Geophysical well (borehole) logging, also known as downhole geophysical surveying or wire-line logging, involves measuring the physical properties of surrounding rocks with a sensor housed in a borehole logging device called "sonde" to derive additional information about the sequence of the rocks penetrated. The record of the measurements as a function of depth is called a well log. Any of the standard geophysical surveying techniques may be adapted for use in borehole logging. These methods include mechanical methods; passive and several active electrical methods involving self-potential, resistivity, induction, and induced polarization; several nuclear (radiometric) methods (natural $\gamma$-ray detection and observations from induced nuclear reactions); acoustic (seismic) logging; and measurement of magnetic and thermal properties (Asquith and Gibson 1982; Sheriff 1991; Kearey et al. 2002; Ofwona 2010; Miroslav 2011).

The properties of penetrated subsurface formations and their fluid contents by these methods are recorded on geophysical logs, measuring their electrical resistivity and conductivity, ability to transmit and reflect sonic energy, natural radioactivity, hydrogen ion content, and temperature and density, etc. The logs are then interpreted in terms of lithology, porosity, permeability, and fluid content. However, drilling mud, mud filtrate, formation water, and hydrocarbon affect the logging measurements (Pickett 1970; Schlumberger 1972, 1974, 1979; Telford et al. 1990; Assaad 2009; Honório et al. 2012). Borehole logs can define the depth to geological interfaces or beds with characteristic geophysical signatures, identify geological formations and formation fluids, provide a means of correlating geological information between boreholes, obtain information on the in situ properties of the wall rock, and evaluate the productive capabilities of reservoir formations (Kearey et al. 2002; Ofwona 2010; Miroslav 2011).

During hydrocarbon borehole drilling, a porous and permeable formation is penetrated by the drill bit; the drilling 
mud invades the formation as mud filtrate as shown in Fig. 5 . The borehole environment of a wellbore in Fig. 5 shows the borehole diameter $\left(d_{h}\right)$, the outside diameter of the drill bit describing the borehole size of the wellbore; and the drilling mud $\left(R_{m}\right)$ acting as the circulating fluid with special viscosity and density to help remove the cutting from the wellbore, lubricate and cool the drill bit, and keep the hydrostatic pressure in the mud column greater than the formation pressure. The invasion of the porous and permeable formation by mud filtrate creates the invasion zones $\left(R_{i}\right.$ and $\left.R_{x o}\right)$ and an uninvaded zone $\left(R_{t}\right)$. The invaded zone consists of a flushed zone $\left(R_{x o}\right)$ where the mud filtrate has completely flushed out the formation's hydrocarbons. The transition zone or annulus zone $\left(R_{\mathrm{j}}\right)$ occurring between the flushed zone $\left(R_{x o}\right)$ and the uninvaded zone $\left(R_{t}\right)$ consists of mixed formation fluids and mud filtrate. The depth of invasion of the mud filtrate into the invaded zone known as the diameter of invasion $\left(d_{i}\right)$ and $\left(d_{j}\right)$ depends on the permeability of the mud cake and not on the porosity of the rock (Schlumberger 1977; Asquith and Gibson 1982; Assaad 2009).

The specific geophysical log types used in hydrocarbon exploration include spontaneous potential (SP), resistivity, porosity, and gamma-ray logs. SP log record directs current-voltage differences between the naturally occurring potential of a moveable electrode running down the wellbore and that of a fixed electrode located at the surface, measured in $\mathrm{mV}$. The SP log is used only with conductive (saltwater-based) drilling muds, to detect permeable beds

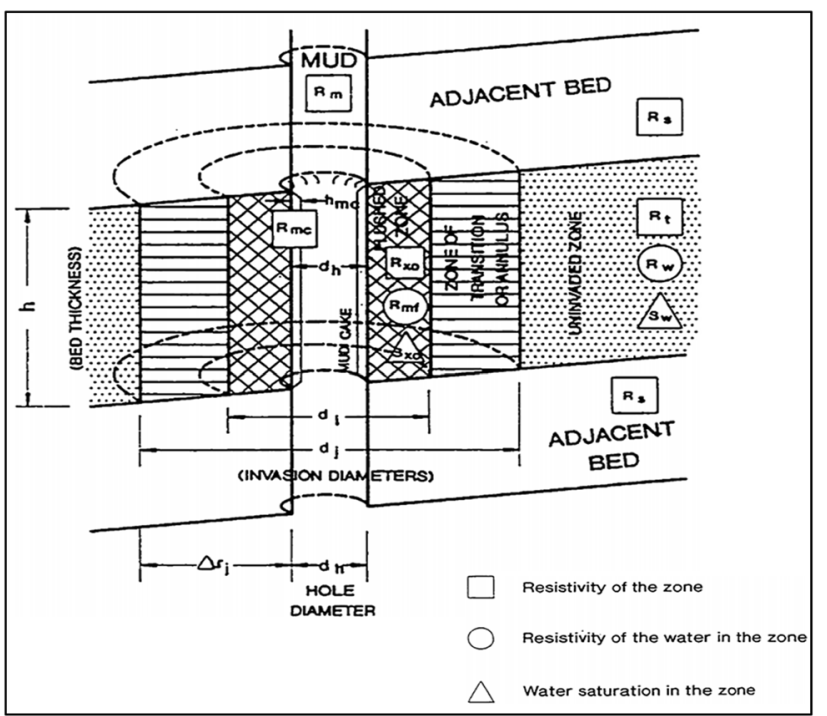

Fig. 5 Diagram of a borehole environment showing the invasion of fluids through the surrounding rock. The dashed lines indicate the cylindrical nature of the invasion. $R_{\mathrm{m}}, R_{\mathrm{mf}}, R_{\mathrm{mc}}, R_{i}, R_{t}, R_{w}$, and $R_{\text {xo }}$ represent drilling mud, mud filtrate, mud cake, invaded zone, uninvaded zone (virgin zone), formation water, and flushed zone, while $S_{\mathrm{xo}}$ and $S_{\mathrm{w}}$ represent water saturation of the flushed zone and water saturation of the uninvaded zone (Asquith and Gibson 1982) and their boundaries, and to determine formation water resistivity and the volume of shale $\left(V_{\mathrm{sh}}\right)$ in permeable beds. The magnitude of SP deflection is due to the difference in resistivity between mud filtrate and formation water, and not on the amount of permeability. In hydrocarbon-bearing zones, the amount of SP reduction is greater than the $V_{\mathrm{sh}}$; this is known as hydrocarbon suppression. The resistivity $\log$ is an electric $\log$ for determining the resistivity, porosity, and hydrocarbon against the water-bearing zone in order to identify the formation's permeable zones. The resistivity $\operatorname{logs}$ include the induction electric log and the dual induction focused $\log$, consisting of the deep induction log, medium induction log, and spherically focused log resistivity curves which measure the resistivities of the deep zone ( $R_{t}$ of the uninvaded zone), medium zone (invaded zone), and shallow zone (flushed zone), respectively. Also, the electrode resistivity logs using salt-saturated drilling mud are included; examples are: normal, lateral, Laterolog, Microlog (a pad type resistivity device that records $R_{\mathrm{mc}}$ ), and Microlaterolog and Proximity Log (both measures flushed zone resistivity), and Spherically Focused Log. The Deep Laterolog and Shallow Laterolog record the resistivities of the uninvaded and invaded zones, respectively, while the microspherical focused log records the resistivity of the flushed zone. The resistivities of the formation, drilling mud, mud cake and filtrate, and formation water are affected by temperature. The porosity $\log$ s include sonic $\log$ s, and density and neutron logs (also known as nuclear logs). The sonic log records formation's matrix porosity. The density log helps to determine evaporite minerals, gas-bearing zones, hydrocarbon density, and to evaluate shaley sand reservoirs and complex lithologies. On the other hand, the neutron logs measure the hydrogen ion concentration in a formation. The lithology logs used in hydrocarbon exploration involve the gamma-ray logs (a type of radiometric logs) which measure natural radioactivity to identify lithologies, correlate zones, and calculate the $V_{\mathrm{sh}}$. Low radioactive concentration with low gamma-ray value is attributed to shale-free sandstones and carbonate; however, as the shale content increases, the gamma-ray log response also increases. Nevertheless, the presence of potassium-feldspar, micas, and glauconite also give rise to gamma-ray response in a shale-free formation (Schlumberger 1972, 1974, 1979; Dresser 1979; Hilchie 1978, 1982; Asquith and Gibson 1982; Telford et al. 1990; Kearey et al. 2002; Assaad 2009; Miroslav 2011).

Formation's water saturation $\left(S_{w}\right)$, which is calculated from the formation of water occupying pores divided by total pore space in the rock, represents an important log interpretation concept because it can be used to determine the hydrocarbon saturation in a formation by subtracting the water saturation from unity (1), which indicate $100 \%$ water saturation (Schlumberger 1977; Dresser 1979; Asquith and Gibson 1982). See given references above for the estimation 
of other formation parameters that are crucial in hydrocarbon exploration, e.g., formation's water saturation $\left(S_{w}\right)$, static spontaneous potential (SSP), sonic porosity (which depends on the interval transit time of formation and fluid in wellbore, and formation's matrix velocity), formation's true porosity, $V_{s h}$, and gamma-ray index $\left(I_{G R}\right)$.

\subsection{Geochemical crude oil exploration methods}

The geochemical oil exploration methods are also conducted to reduce problems associated with exploration and to identify molecular composition and isotropic composition of gases; biomarker composition of oils and hydrocarbon maturity, a continuation of the reservoir; and hydrocarbon migration and accumulation processes. The biomarker found in oils, rock extracts, sediments, and soil extracts is analyzed using gas chromatography and a mass spectrometer to estimate the migration pathway of hydrocarbon deposits. The isotopic analysis involving isotopic ratios is analyzed to determine the origin of hydrocarbon and to estimate the accumulation of oil and gas (Sharma and Chaturvedi 2014). Besides, when the well has recovered from the effects of cooling during drilling, a flow test is conducted to evaluate its mass flow rate, enthalpy, and chemical characteristics of the discharged fluids. This test is very important because different wells are discharged under different control conditions to get the characteristic curve and to select the operating conditions for the turbines in the power plant (Ofwona 2010).

\section{Overview of crude oil processing}

In almost all crude oil refineries, the first processing unit is the crude oil distillation unit (CDU). The CDU is designed and tasked with the distillation of the unprocessed crude into several fractions according to their boiling points (Kister 1992). The crude distillation unit (CDU) system is divided into two; the atmospheric distillation unit (ADU) and the vacuum distillation unit (VDU). Alongside these two integral components, a CDU system also incorporates crude oil furnaces, heat exchangers network (HEN), and distillation towers. A schematic diagram showing the setup of a crude oil distillation unit is shown in Fig. 6. The numerous physical and chemical processes undertaken by crude oil in an oil refinery are geared toward the production of useful products such as gasoline, jet fuel, diesel fuel, kerosene, etc. The basic principle employed in petroleum refining is the longer the carbon chain, the higher the temperature at which the compound boils (Dincer and Rosen 2013).

Crude oil distillation begins with the fractionation of the crude oil in an atmospheric distillation column according to their respective boiling point ranges. The varying products obtained can be classified in order of increasing volatility into residuum, gas oils, middle distillates, light distillates, and gases. The crude oil is first desalted, the desalted crude is then sent to the atmospheric distillation column for fractionation into straight-run products such as naphtha, gas oil, kerosene, etc. The residual is then sent to the vacuum distillation column for further distillation at higher temperatures (Cheremisinoff and Rosenfeld 2009). The primary endproducts of crude oil distillation are described shortly below.

\subsection{Gasoline}

Gasoline is a clear petroleum-derived flammable liquid that is used primarily as a fuel in most spark-ignited internal combustion engines. Upon enhancement using various additives, its main components are organic compounds gotten from the fractional distillation of crude oil (EIA 2017). Gasoline's combustive ability is aided by the presence of oxygen-containing compounds. The specific gravity of gasoline ranges from 0.71 to 0.77 (Demirel 2012). Early ignition, known to reduce efficiency in engines and cause knocking, is a property that must be avoided in a good gasoline blend. This property is mirrored by the gasoline's octane rating. Lead and its compounds were once commonly used in a bid to increase the octane rating of fuels, controlling corrosiveness, and improving chemical stability. However, it has been prohibited in many countries (Kessler 2013).

\subsection{Kerosene}

Kerosene is a relatively low viscous clear liquid obtained as a product from the fractional distillation of crude oil between 150 and $275^{\circ} \mathrm{C}$. It contains compounds with carbon chains between 10 and 16 carbon atoms per molecule (Collins 2007). These compounds (accounting for $75 \%$ by volume) are majorly straight/branched-chain alkanes and cycloalkanes, regardless of the source or processing technology applied to the crude oil, while aromatic hydrocarbons in kerosene account for less than $25 \%$ by volume (AIP 2010).

\subsection{Diesel fuel}

Diesel fuel is any liquid fuel used in diesel engines, whose fuel ignition takes place, without any spark, as a result of compression of the inlet air mixture and then injection of fuel (Knothe et al. 2006). Diesel is mainly composed of $75 \%$ paraffin and $25 \%$ aromatics (Date 2011).

\subsection{Liquefied petroleum gas}

Liquefied petroleum gas finds extensive usage as a refrigerant and aerosol propellant. In a bid to reducing the damage done to the ozone layer, it has successively displaced the 


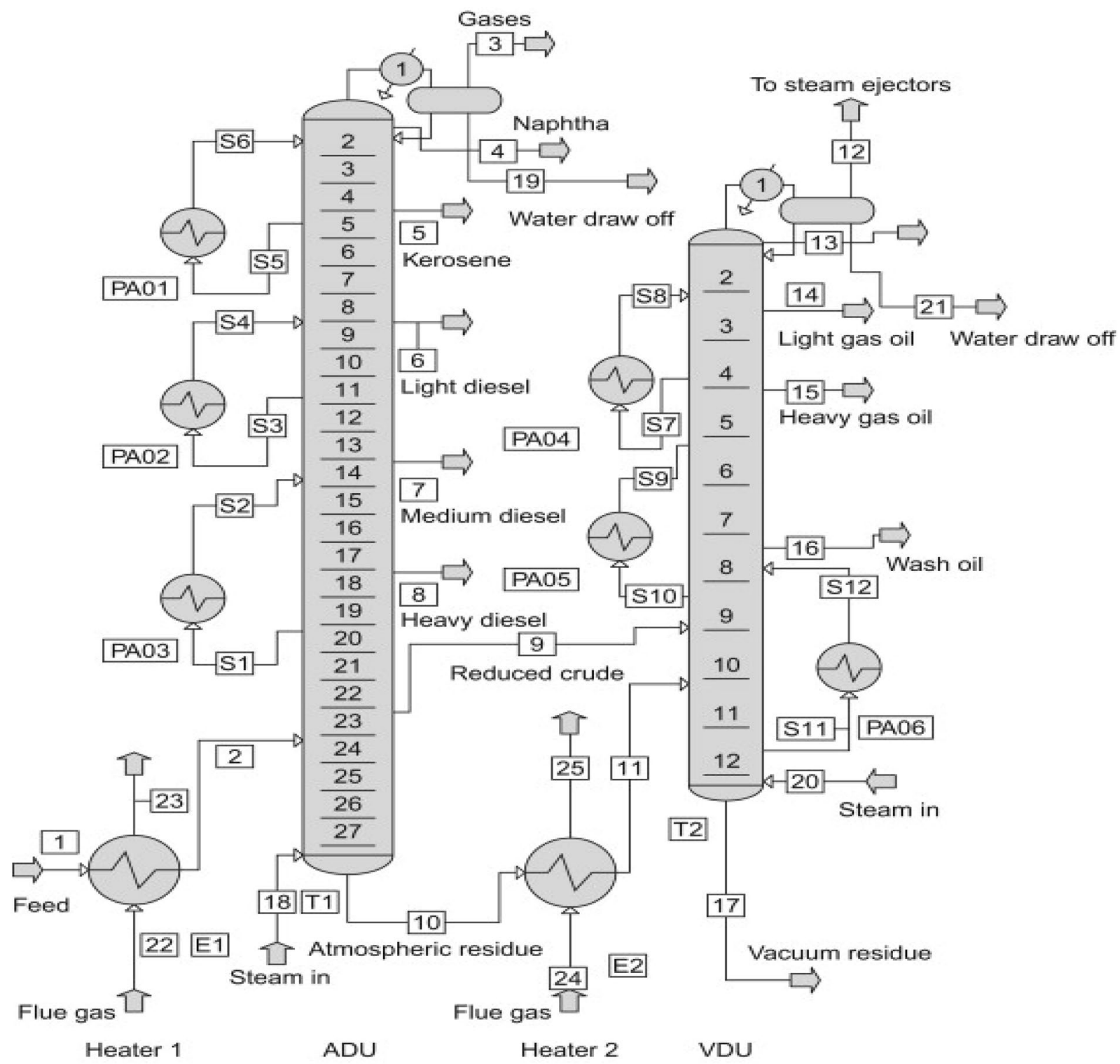

Fig. 6 Schematic diagram of a crude oil distillation unit (Al-Muslim et al. 2005)

initial use of chlorofluorocarbons. It is referred to as Autogas when used as a vehicle fuel. It is also a promising feedstock for the production of olefins e.g., propylene, ethylene, butene, etc., in the petrochemical industry ( $\mathrm{Li}$ et al. 2020; Orozco et al. 2020).

\section{Socio-economic impacts of crude oil exploration and processing}

The exploration and processing of crude oil in Africa has its attendant socio-economic impacts. At the end of 2007, Africa was referred to as the fastest-growing source of energy with 117.481 billion barrels of crude oil or $9.49 \%$ of the world's reserves (Nyemah 2011). Largely, oil exploration has its benefits to the economy of a nation and the world at large for example, the revenue from the oil sector has been the mainstay of the economy of the countries producing it in Africa; as it is also infused into other sectors for developmental purposes (Olujimi et al. 2011; Mensah and Casadevall 2019). In today's modern society, however, the quest for rapid development and making life comfortable for human beings has rather taken overriding priority over environmental safety.

The largest oil producers globally are the United States, Russia, and Saudi Arabia accounting for 54\% of the total world production (Investopedia 2020) with Africa also not relenting currently with 10 oil-producing countries. In 
global trade, oil and gas are the major internationally traded commodities and this is because they are easy to transport. There have been more than 275 new oil fields discovered in West Africa since 2000, according to a U.S. Geologic Survey Fact Sheet issued in February 2010 (Kramer 2010). Proper management of natural resources and the revenue generated from trade and investment in petrochemicals and affiliated products, can be harnessed for economic growth, reduce unemployment, infrastructural development, alleviate property and hunger in the African continent (Nyemah 2011; Faria 2020). However, despite the discovery of oil fields and deposits in Africa within the last century, poor resource management, lack of local investment, and corruption have inhibited desired growth and development, yet the adverse effect of exploration and processing is enormous.

The Nigerian government, for instance, exercises absolute control over property rights. In other words, they exercise the sovereign power to take seizure of any landed property for use (Boele et al. 2001; Agbogidi et al. 2005). Earlier reports suggested that the total wealth accrued from crude oil exploration in Nigeria get siphoned by only $1 \%$ of the entire population (Junger 2007; Brown and Tari 2015). Reports between 1970 and 2020 and the average price of barrel oil and a gallon of gas between the period in review, suggest that $\$ 669$ billion in revenue was generated from the sales of crude oil between 1970 and 2010. Furthermore, between 1999 and 2010, over 742 million cubic meters of gas were produced, if harnessed would have been equivalent to $\$ 192$ billion, and $587,375,000$ cubic meters were flared, which represents a loss in revenue of around $\$ 151.3$ billion (Audu et al. 2016). Nigeria is regarded as the number one crude oil producer in Africa, the seventh-largest exporter of crude oil in the world, and holds the 10th biggest processed gas reserve in the world (Amnesty International 2006; Donwa et al. 2015). Despite the massive earning from oil, Nigeria is ranked among the poorest and heavily indebted countries in the world (Agbiboa 2013; Investopedia 2020). Over $70 \%$ of its estimated 200 million people live on less than \$2 US per day, due to corruption and mismanagement of resources and revenue according to the corruption perception index (CPI) reports (Hope 2017). The diversion of funds from public coffers to certain individuals, and award of oil blocks, contracts, licensing, and production rights to individuals have impaired economic growth and led to civil war, banditry, and insurgency in Nigeria.

The rampant corruption of government officials, particularly in Africa, is a downside to the exploration and processing of crude oil in Africa. A large number of host communities of crude oil deposits in Africa suffer from a lack of infrastructure. Fertile soils and clean rivers are integral resources required by residents of local communities to ensure their economic wellbeing, which has been negatively impacted by crude oil processing, exploration, and transportation (Ehirim et al. 2018). Most of the communities are deprived of a potable water supply due to oil spills emanating from crude oil exploration (Junger 2007). The resulting influence of the oil spills into water bodies is a threat to aquatic life which then results in aggravating hunger and poverty (Pittock et al. 2018). Agricultural farmlands are also affected in the process due to runoffs from crude oil deposit areas, thus turning originally fertile soils into wastelands. The economic downturn of this is a reduction in crop yield and productivity (Sam et al. 2017; Chijioke et al. 2018), thus affecting sales and subsequently the gross domestic product from agriculture. Gas flaring is characterized by the release of harmful gases and particulate may pose health threats to both humans and animals (Otitoloju and Dan-Patrick 2010). Over 250 toxins, which include polycyclic aromatic hydrocarbons (PAHs), hydrogen sulfide, toluene, benzene, sulfur dioxide, nitrogen dioxides, xylene, etc., have been detected in flared gases; some of which are responsible for acid rain, ozone depletion, global warming, cancer, and other harmful effects (PAHs) (Giwa et al. 2019). Thus, the indiscriminate release of particulate matter and precursor gases around oilproducing communities may call for concern.

Furthermore, quite a large number of oil-producing nations in Africa are heavily reliant on the output from the processing of crude oil. The corruption embedded in the system makes little room for accountability and as such lump sums are siphoned elsewhere. This leads to an impairment in the infrastructural development of oil processing since most of the money is being siphoned elsewhere. The socioeconomic structure of many African countries has been altered, as a result of the operation of crude oil exploration activities, resulting in a lack of accountability and less citizen participation (Kyomugasho 2016). Table 1 reveals a significant discrepancy in the human development indices to the amount of oils produced by most of the Countries listed. Countries with significantly lesser revenue generated from oil production fared better in terms of human development and capacity building. This points to the fact that revenues do not automatically transform poor economies into thriving ones, except the revenue is efficiently managed, effectively redistributed, and properly harnessed for diversified local investments.

Nigeria continues to experience national under-development despite her enormous exploration and processing of crude oil. This is largely due to neglect experienced by other sectors of the economy as a result of the large revenue incurred from crude oil, thus making the nation a mono-culture economy (Adefolaju 2014). The failure of most African governments to mitigate corruption and associated risks of oil pollution has reportedly contributed to militant activities in the crude oil-producing regions (Tantua and Kamruzzaman 2016; Babatunde et al. 2018). In addition, poverty is a major experience of crude oil-host communities in Africa 
(Sam and Zabbey 2018). Crude oil is majorly found in rural areas in Africa. The technological expertise required for its exploration and processing is oftentimes imported due to the low level of education of persons living in such communities. It was reported that about $70 \%$ of individuals resident in the Niger Delta area of Nigeria are living below US $\$ 1$ per day (Amnesty International 2006).

In Angola, even though the first commercial oil discovery was made in 1955 and the oil industry has grown exponentially since then, yet economic growth has fluctuated substantially averaging just about 5\% per annum between 1985 and 2015 (Mohammed 2018). In the wake of oil discovery, civil war struck in Angola between 1975 and 2002, thus limit expected growth and development (Malaquias 2001). However, between 2006 and 2015, oil accounted for 97\% of Angola's export and $45 \%$ of its gross domestic product (GDP) (World Bank, 2017). In Angola to date, over-dependence on oil exports as the major contributor to economic growth is a major concern for policymakers, especially due to the falling price of oil and global recession during the COVID-19 pandemic.

Libya is renowned traditionally for agriculture until the discovery of oil in 1959 (Blake 1969). Since its discovery, crude oil is the major source of revenue (50\% of GDP, 97\% of exports, and $75 \%$ of national revenue), and plays a dominant role in the socio-economic development of Libyan society (El-Sharif 2005). Although the advent of oil has brought about tremendous prosperity, the country has lost economic diversity and affected the provision of certain goods and services, especially during the ongoing exogenous world oil price instability (Ali and Harvie 2013). In Egypt, the export of crude oil has declined as a result of global recession and global market instability, leading to the rapid decline in Egyptian's living standards, welfare benefits, and public outrage from labor unions and government employees. The plummeting price of crude oil has increased the need to borrow from the International Monetary Fund, leading to unpalatable structural reforms, austerity measures, and currency devaluation (El-Shimy 2016).

The livelihood structure of residents of oil communities in Ghana has been altered due to a ban on fishing in the oil-producing areas (Nguah and Mensah 2016; Akakpo et al. 2018), thus affecting the standard of living in the process. Deprivation, occupational dislocation, abject poverty, rural-urban drift, and social conflicts are some of the many peculiarities associated with these oil-producing areas due to crude oil exploration and processing (Mugisa 2016; Dauda 2017; Matemilola et al. 2018). These impacts of oil exploration are predominantly felt by local communities due to the possibility of having their social and communal values affected (Fentiman and Zabbey 2015). For instance, in a bid to ushering in a new year in the Niger Delta area of Nigeria, community members undergo festive bathing as it is believed to be integral to the prosperity of the community in the new year. Cultural beliefs like this, among many others, have been obliterated due to oil spills emanating from crude oil exploration (Onuegbulam 2018; Onyena and Sam 2020). Other economically viable aquatic species such as Eastern oyster (Crassostrea virginica), Nile tilapia (Oreochromis niloticus), rainbow trout (Oncorhynchus mykiss) are negatively impacted by oil pollution (De Anna et al. 2021; Garcia et al. 2020; Olajuyigbe et al. 2020). This has affected the ecological profile, the economy of the oil-producing region, and the lifestyle of people in the region. The corporate activities of multinational oil corporations (MNOCs) and suspected unethical practices associated with MNOCs have resulted in social movements against them by host communities, human rights groups, and non-governmental organizations (NGOs). The agitations are mainly hinged on the attitude of MNOCs toward nature, human health, and the rights of citizens (Kalu and Ott 2019).

\section{Environmental pollution as a result of crude oil exploration and processing}

Environmental pollution due to crude oil exploration occurs due to an increase in global demand, uncontrolled exploration practices, poor waste management, etc. (Garang Kuch and Bavumiragira 2019). Despite its growing importance across the world, crude oil exploration leaves the environment polluted. The impact of environmental pollutions across the world, especially in Africa, has far reached worrying proportions (Kelishadi 2012). The strides being made in the developing world particularly in Africa through industrialization and economic development have undoubtedly increased exposure to environmental pollution (Briggs 2003). Pollutants can cause adverse effects to human health from early life and this includes cardiovascular disorders, mental disorders, allergies, and respiratory disorders (Kelishadi 2012).

Despite the economic benefits of crude oil discovery and exploration in Africa, oil exploration no doubt has far-reaching adverse effects on environmental compartments; air, land, water as well as all living things on earth. Some avoidable occurrences, which are often mismanaged in Africa include oil spillage, gas flaring (causing various gas emissions), noise, and improper waste management (wastewaters and solid wastes) (Pathak and Madalia 2012). In exploration and exploitation of oil and gas, the major environmental pollutants are; (i) effluent water contaminated with oily effluents (oil \& grease), chemicals, and solids from drilling fluid, (ii) formation water produced along with crude oil, and (iii) gaseous emissions having $\mathrm{CO}, \mathrm{SO}_{2}, \mathrm{NOx}$, hydrocarbons and fine particulate matter from the gas flare. The contamination of water, soil, and air by oil and gas wastes as well as its 
associated byproducts is a possibility. Reports by citizens have shown the relative effect of production and drilling activities on the contamination of surface waters, soils surrounding well sites, and water wells; air emissions emanating from wellheads, pipelines, drilling sites, compressor stations, and several other oil and gas field infrastructure have been reported to pose air quality concerns (Jiang et al. 2020). Other significant environmental threats are those emanating from the dust particles left from drilling which can coat the surrounding areas, as well as flames produced upon combustion of natural gas in the oil fields which are known to cause air pollution. Gaseous emissions include $\mathrm{SO}_{2}, \mathrm{CO}$, hydrocarbons, NOx, and particulate from the gas flare. In addition, accidents, illegal dumping of oil barrels and produced water, and oil spills also lead to distressing health and ecological consequences that may persist for decades.

Several activities in crude oil processing ranging from extraction, refining, transportation, and gas flaring introduce greenhouse gases especially carbon dioxide into the atmosphere. The process of burning fossil fuels (coal), oil, and gas leading to the emission of carbon dioxide (a greenhouse gas) has led to global warming raising serious environmental challenges (Darkwah et al. 2018; Jiang et al. 2020). Also, the flaring of gases rich in a liquid produces smoke having aerosols that also contribute to global warming (FOE 2004; Darkwah et al. 2018). Acid rain which is caused by some activities involved in the crude oil exploration process has adverse effects on the ecosystem. Oil spills which are seen as the unlawful release of liquid petroleum hydrocarbons within the environments, accidentally or due to intentional human factors have the potentials of adversely impacting the different coastal and marine habitats, wildlife, fisheries, and even human activities (Sojinu and Ejeromedoghene 2019). According to a study by Ordinioha and Brisibe (2013), it was reported that oil spills could lead to a $60 \%$ reduction in household food security and were capable of reducing the ascorbic acid content of vegetables by as much as $36 \%$ and the crude protein content of cassava by $40 \%$ thus resulting in a $24 \%$ increase in the prevalence of childhood malnutrition (Ordinioha and Brisibe 2013).

Various kinds of waste may be generated in the processing of crude oil and when not properly handled becomes a threat to the environment. Oil pollution affects the waterretaining capacity of soils, makes them repel water, blocks soil pores thereby affecting the movement and flow of soil water (Hewelke et al. 2018; Wei et al. 2020a, b Wei et al. 2019). The physicochemical and biochemical properties of soils polluted by crude oil are altered (Dong et al. 2020; Marinescu et al. 2011; Zhao et al. 2020). It was shown that oil and gas exploitation activities resulted in land degradation in a study carried out in Ondo state, Nigeria (Olujimi et al. 2011). Marinescu et al. (2011) reported that the organic carbon content and the carbon/nitrogen $(\mathrm{C} / \mathrm{N})$ ratio of polluted soils were increased. Salts absorbed by the soil from drilling fluids during disposal can alter the physical properties of the soil indirectly impacting plant growth (Pathak and Mandalia 2012). Research has shown that soils around areas where gas flaring and spillage occur experience soil acidification, resulting in the loss of their fertility and their capacity for agriculture over some time (Zhao et al. 2020).

\subsection{Impact on humans and aquatic species}

Crude oil exploration and oil spills have negative impacts on the surrounding environment causing hazards, both short and long term, on the neighboring vegetation, animals, and even humans (Barron et al. 2020; Bebeteidoh et al. 2020; Beyer et al. 2020; Vargas et al. 2020). The esthetics, ecological profile, economy of the region affected, and even the lifestyle of people resident in the area are not spared of these damages. Contaminated soils negatively affect building constructions through the degradative effect on their foundations, leading to the collapse of buildings and death (Alfach and Wilkinson 2020). Polycyclic aromatic hydrocarbons, one of the toxic compounds found in crude oil have been documented to cause cancer and cardiovascular problems in aquatic life (Brette et al. 2017; Dubansky et al. 2018; Moorthy et al. 2015). Humans exposed to oil pollution over some time and their offspring are also prone to cancer and heart defects (McKenzie et al. 2019; Stenehjem et al. 2015; Strelitz et al. 2019). Crude oil-related pollution has increased greatly and this has been a source of concern to researchers.

Exposure of the fish Achirus lineatus to the water contaminated with light crude oil led to changes in the normal bacteria composition of the gut. These changes were observed both over a short period of $48 \mathrm{~h}$ (Améndola-Pimenta et al. 2020) and a severe exposure of 28 days (Cerqueda-García et al. 2020). Although the oxygen concentration in the gastrointestinal tract of the fishes was not measured, it was presumed that toxic exposure to crude oil and gas, could lead to oxygen depletion, since bacterial activity affects oxygen availability and vice versa. Ackerly and Esbaugh (2020) reported that 24-h exposure to crude oil and then hypoxic conditions affected the metabolic activities and aerobic performance of the red drum (Sciaenops ocellatus) via an additive effect unlike when the fishes were subjected to each condition individually. Khursigara et al. (2021) also observed that the specific growth rate of aquatic species was lowered among weeks after crude oil exposure. The reduced growth rate corresponded with a reduction in the standard metabolic rate but did not affect their aerobic performance. Polycyclic aromatic hydrocarbons in crude oil have been reported to impair vision in fish. Magnuson et al. (2020) found out that embryonic zebrafish (Danio rerio) exposed to crude oil exhibited cell death in the retina and bradycardia. A reduction in cardiovascular performance was observed 
in the Gulf killfish (Fundulus grandis) exposed to oil. The hatching success of the killfish eggs was also reduced when they were exposed to crude oil (Gurung et al. 2021).

Large-scale oil pollution has affected the avian population, leading to their mortality. Various species of seabirds and coastal birds have experienced effects ranging from physiological to lethal such as inflammation, suppression of the immune system, oxidative cell damages, reduced reproductive success, organ malfunctions, hemolytic anemia, and susceptibility to other diseases (Goethe 1968; Briggs et al. 1996; Yamato et al. 1996; Esler et al. 2000; Giese et al. 2000; Golet et al. 2002; Alonso-Alvarez et al. 2007; Fallon et al. 2018; 2020). Improper waste disposal system in the process of oil exploitation is a major threat to humans and animals. Runoffs could occur into water bodies leaving them toxic to marine animals.

\section{Existing and emerging remediation approach for crude oil pollution}

In the last few decades, environmental scientists have made several attempts to develop biochemical, thermal, and physical methods for the remediation of polluted water (Adeola and Forbes 2021a, 2021b). Existing remediation options include volatilization, emulsification, chemical oxidation, biodegradation, and adsorption. Gong et al. (2020) recently developed a highly effective, fast-action, photothermal $\mathrm{Ti}_{3} \mathrm{C}_{2} \mathrm{~T}_{\mathrm{X}}$ MXene based sponge, based on the hypothesis that when crude oil is heated, the viscosity reduces, and it can be adsorbed easily ( $\mathrm{Li}$ et al. 2018). A graphene oxidemelamine sponge composite effectively cleaned up crude oil from water (Wang et al. 2020). In less than $12 \mathrm{~min}$, with light irradiation, crude oil 95 times the weight of the composite was absorbed in situ. Wong et al. (2020) also reported the ability of magnetic graphene oxide composites to serve as demulsifiers in crude oil removal. Wood sawdust-coated magnetite nanoparticles functionalized with stearic acid were demonstrated to effectively remove oil from seawater by adsorption (Soliman et al. 2020), while Kamgar et al. (2020) functionalized sawdust with Iron oxide nanoparticles also recorded efficient crude oil removal from aqueous solution.

In soils, a zeolitic imidazole framework coated on carbon fiber; activated carbon, and diatomite were applied on polluted soil as an adsorbent and the total petroleum hydrocarbon was significantly reduced (Shahmirzaee et al. 2020; Vasilyeva et al. 2020). Polycyclic aromatic hydrocarbons were successfully broken down in crude oil-infected sediment by Rhizophora mangle; however, the field application of this method is in doubt due to physical and biological variations that could occur in the natural environment (Verâne et al. 2020). Ekperusi et al. (2020) and Enibukun and Boboye
(2020) posited that Lemna paucicostata, a duckweed species, significantly degraded hydrocarbons in contaminated wetlands. Six (6) Rhizobia were isolated from legumes; however, $R$. leguminosarum BIHIB1217 and R. leguminosarum $\mathrm{N} 871$ were the most efficient in breaking down crude oil in soils. A controlled greenhouse experiment revealed that Vetiveria zizanioides could be used in the bioremediation of contaminated soils (Kiamarsi et al. 2020), with the researchers recommending further research to determine its applicability in the field. Other plants such as Cyperus brevifolius, Mirabilis jalapa L., Tectona grandis, Gmelina arborea, Sebastiania commersoniana, corn (Zea mays), and soybean (Glycine max) are some of the plants that have been documented to clean up the crude oil-polluted environment (Issoufi et al. 2006; Agbogidi et al. 2007; Peng et al. 2009; Ramos et al. 2009; Basumatary et al. 2012).

Emerging technologies/methods include the use of hydrocarbonoclastic bacteria native to the environment and bioaugmentation, for environments heavily polluted by crude oil and heavy metals (Ali et al. 2020). This is a proven integrated approach to remediation (Adeola and Forbes 2021a, b). Solid inoculants of LZ-2 bacteria were found to degrade hydrocarbons found in crude oil ( $\mathrm{Li}$ et al. 2021). Bioaugmentation was also the rationale behind the use of bacterial strains Rhodococcus rhodochrous and Nocardia farcinia to successfully break down crude oil in water bodies (Rodrigues et al., 2020). Exiguobacterium sp. A0-11, Bacillus licheniformis, Pseudomonas aeruginosa, Pseudomonas putida, and Rhodococcus sp. Moj-3449 aided the removal of crude oil from contaminated soil by breaking down long-chain $\mathrm{n}$-alkanes in water bodies (Muangchinda et al. 2020; Binazadeh et al. 2020). Biosurfactant produced from Bacillus subtilis strain Al-Dhabi-130 and Staphylococcus sp. CO100 degraded crude oil and reduced surface tension (Dhabi et al. 2020; Alnuaimi et al. 2020; Annie et al. 2020; Deivakumari et al. 2020; Khanpour-Alikelayeh et al. 2020; Maamar et al. 2020; Ławniczak et al. 2020).

However, the application of these bacteria species may be problematic in heavily polluted environmental compartments, especially toward restoring them to their pristine conditions. Besides, phytoremediation holds an added advantage of reducing air pollution by absorbing excess atmospheric $\mathrm{CO}_{2}$; however, it may require many years to achieve significant crude oil remediation. Furthermore, some of the remediation methods are not robust enough to deal with heavily polluted soil and water. A number of the remediation method discussed in this review and presented in Table 2, are still at the prototype stage, awaiting field trials, while others have been used on a field scale and are effective; however, several challenges and limitations still exist, such as high operational cost, fouling, non-regenerable materials, nonecofriendly processes, long treatment time, generation of a large amount of sludge or secondary pollutants, etc. 


\section{Conclusion and policy implications}

The occurrence of organic-rich, oil-prone Type I, II, and mixed II/III kerogens in giant hydrocarbon fields in the sedimentary basins in Africa is majorly responsible for the huge commercial accumulation of hydrocarbon in the basins. The oil-prone source rocks, namely shales and carbonates contain preserved organics from algae and phytoplankton. The organic-rich shales and carbonates with increasing temperature may generate and expel liquid hydrocarbon. Most of the source rocks in the hydrocarbon fields are within the oil window (0.60-1.20 $\left.\mathrm{VR}_{0} \%\right)$. Hydrocarbons are expected to be trapped mainly within reservoir rocks, with intrinsic petrophysical properties of shallow stratigraphic horizons.

The seepage/leakage of effluent water to the surrounding areas is a major source of pollution and to minimize/ control the seepage, several proactive measures should be taken into consideration: (i) construction of ring bund on the periphery of the drill site, (ii) construction of peripheral trench along with boundary wall, (iii) compartmentalization of drill site, and (iv) construction of cutting pit, waste pit, oil pit, etc. At the offshore drilling rigs and production plants, there is a need for the treatment of effluent water and the retrieval of oil spills from the treatment unit.

\subsection{Policy implications}

The 1992 Rio Declaration on Environment and Development affirms that human beings should be given priority concern in the quest for sustainable development (UNEP 1997) and advocates for the adoption of ecofriendly processes for environmental safety. Furthermore, in the face of global recession and pandemic, emerging reality calls for a more drastic approach to addressing the plummeting revenues, economic hardship, environmental pollution, and corruption that currently plagues the continent. Due consideration should be given to the following by policymakers:

1. Strict laws and penalties should be enacted and implemented against quasi-criminal conduct, corruption, and crimes such as pipeline vandalism, economic fraud, and oil bunkering, which have been reported to have a direct influence on the economic growth and collective wealth of oil-producing countries in Africa.

2. Revenue sharing formula and budgetary allocations should be reviewed as a high percentage of revenue generated from crude oil sales and taxes paid by multinational companies should be channeled toward the provision of quality education, health care, and infrastructures that will benefit the citizens of oil-producing countries in Africa.
3. Job creation and involvement of communities in the safeguard, maintenance, and monitoring of oil and gas pipelines should be mainstreamed into the social responsibilities of oil companies, which will culminate in improving the quality of life of host communities.

4. Strict environmental laws and severe sanctions should be enacted to curtail gas flaring and indiscriminate waste disposal, and stakeholders in the oil and gas industry must ensure compliance and adherence to regulations.

5. Adequate and prompt compensation should be made available to affected communities, and swift remedial activities should be undertaken whenever there are spills.

6. There is a need for the development of leftover drill sites and afforestation around the site of exploration should be considered, as it is a viable means of restoring ecological balance and pristine environmental conditions, which has been greatly altered.

In conclusion, there is a need for enlightenment toward economic diversification for sustainable development, especially in the face of depleting and irreplaceable capital or natural resources currently being exploited in the environment. Oil revenue should be used to create sustainable and diverse investments for long-term benefits for future generations while addressing current challenges such as poor healthcare, food scarcity, environmental pollution, corruption, and other challenges responsible for the low human development indices in Africa.

Acknowledgements The authors acknowledge their respective academic supervisors for the mentorship and training received during postgraduate studies.

\section{Declarations}

Conflict of interest The authors declare that there are no known competing financial interests or any conflicting interests that could influence the works reported and publishing of this paper.

\section{References}

Ackerly KL, Esbaugh AJ (2020) The additive effects of oil exposure and hypoxia on aerobic performance in red drum (Sciaenops ocellatus). Sci Total Environ. https://doi.org/10.1016/j.scitotenv. 2020.140174

Adefolaju T (2014) Socio-economic impact assessment of a monoculture economy: the case of Nigeria. J Sociol 2(1):225-239

Adeola AO, Forbes PBC (2021a) Advances in water treatment technologies for removal of polycyclic aromatic hydrocarbons: existing concepts, emerging trends, and future prospects. Water Environ Res 93(3):343-359. https://doi.org/10.1002/wer.1420

Adeola AO, Forbes PBC (2021b) Antiretroviral drugs in African surface waters: prevalence, analysis and potential remediation. Environ Toxicol Chem. https://doi.org/10.1002/etc.5127 
AfDB (African Development Bank) 2008 African Development Bank/African Development fund, tunis. African energy. Website database (www.africa-energy.com)

AfDB (African Development Bank) 2009 Oil and gas in Africa. Joint study by the African Development Bank and the African Union. Oxford University Press, UK. p 272

Agbiboa DE (2013) Corruption and economic crime in Nigeria: social and economic perspectives. African Sec Rev 22(1):47-66

Agbogidi OM, Okonta BC, Dolor DE (2005) Socio-economic and environmental impact of crude oil exploration and production on agricultural production: a case study of Edjeba and Kokori communities in Delta State of Nigeria. Global J Environ Sci 4(2):171-176

Agbogidi OM, Dickens Dolor E, Mercy Okechukwu E (2007) Evaluation of Tectona grandis (Linn) and Gmelina arborea (Roxb) for phytoremediation in crude oil contaminated soils. Agric Conspec Sci 72(2):149-152

Aissaoui MN, Bédir M, Gabtni H (2016) Petroleum assessment of Berkine-Ghadames Basin, southern Tunisia. AAPG Bull 100:445-476. https://doi.org/10.1306/01141612083

Ajaegwu NE, Ozumba BM, Adejinmi KT (2014) Sequence architecture of late Miocene to early Pliocene sediments of shallow offshore, Niger Delta, Nigeria. Nigerian Assoc Petroleum Explor Bull 26(2):39-45

Akakpo GS, Ewedji CS, Atta-Mensah I, Tsatsu W (2018) The operational and economic impact of crude oil exploitation on fishing activities in the Jomoro District of Ghana. Int J Social Sci Human Res 6(2):123-129

Akingboye AS, Ogunyele AC (2019) Insight into seismic refraction and electrical resistivity tomography techniques in subsurface investigations. Mining Geol Petroleum Eng Bull 34(1):93-111

Akpata U, Bredenhann C, White D (2013) From promise to performance: Africa oil and gas review. Report of current developments in the oil and gas industry in Africa. PricewaterhouseCoopers (PwC), South Africa. p 44. Website database (www. pwc.co.za)

Al-Dhabi NA, Esmail GA, Arasu MV (2020) Enhanced production of biosurfactant from bacillus subtilis strain al-dhabi-130 under solid-state fermentation using date molasses from saudi arabia for bioremediation of crude-oil-contaminated soils. Int J Environ Res Public Health 17(22):1-20. https://doi.org/10.3390/ijerp h17228446

Alfach MT, Wilkinson S (2020) Effect of crude-oil-contaminated soil on the geotechnical behaviour of piles foundation. Geotechnical Research 7:76-89

Ali AH (2020) Phytoremediation for crude oil-contaminated soil using organic wastes. Plant Archives 20:664-667

Ali I, Harvie C (2013) Oil and economic development: libya in the post-Gaddafi era. Econ Model 32:273-285. https://doi.org/10. 1016/j.econmod.2013.01.022

Ali N, Khanafer M, Al-Awadhi H, Radwan S (2020) Self-cleaning of very heavily oil-polluted sites proceeds even under heavy-metal stress while involved bacteria exhibit bizarre pleomorphism. Ecotoxicol Environ Saf. https://doi.org/10.1016/j.ecoenv.2020. 110717

Al-Muslim H, Dincer I, Zubair SM (2005) Effect of reference state on exergy efficiencies of one-and two-stage crude oil distillation plants. Int J Therm Sci 44(1):65-73

Alnuaimi MT, Taher TA, Aljanabi ZZ, Adel MM (2020) High-resolution gc/ms study of biodegradation of crude oil by bacillus megaterium. Res Crops 21(3):650-657. https://doi.org/10.31830/ 2348-7542.2020.101

Alonso-Alvarez C, Munilla I, López-Alonso M, Velando A (2007) Sublethal toxicity of the Prestige oil spill on yellow-legged gulls. Environ Int 33(6):773-781
Améndola-Pimenta M, Cerqueda-García D, Zamora-Briseño JA, Couoh-Puga D, Montero-Muñoz J, Árcega-Cabrera F, del RíoGarcía M (2020) Toxicity evaluation and microbiota response of the lined sole Achirus lineatus (Chordata: Achiridae) exposed to the light petroleum water-accommodated fraction (WAF). $\mathrm{J}$ Toxicol Environ Health Part A 83:313-329

Amnesty International (2006) Nigeria: oil, poverty and violence. Archived 19 Aug 2007 at https://web.archive.org/web/20070 819155442/http://www.web.amnesty.org/library/Index/ENGAF R440172006?open\&of=ENG-NGA

Annie G, Sheela AM, Ilamathi R (2020) Fate of crude oil in soil treated with pseudomonas putida immobilized on coconut coirpith a lowcost biocarrier. Soil and Sediment Contamination 29(7):770 787. https://doi.org/10.1080/15320383.2020.1771277

Anyanwu JC, Abderrahim K, Feid A (2010) Crude oil and natural gas production in Africa and the global market situation. Commodities Brief 1(4):1-17

Asquith GB, Gibson CR (1982) Basic well log analysis for geologists. Methods in exploration series. The American Association of Petroleum Geologists, Tulsa Oklahoma, USA, p 234

Assaad FA (2009) Surface geophysical petroleum exploration methods. Field methods for petroleum geologist: a guide to computerized lithostratigraphic correlation charts case study: Northern Africa. Springer-Verlag, Berlin Heidelberg, pp 21-23

Audu A, Jimoh A, Abdulkareem SA, Lawrence O (2016) Economics and environmental impacts of oil exploration and exploitation in Nigeria. Energy Sources Part B 11:251-257

Babatunde BB, Zabbey N, Vincent-Akpu IF, Mekuleyi GO (2018) Bunkering activities in Nigerian waters and their Eco-economic consequences. In: The political ecology of oil and gas activities in the nigerian aquatic ecosystem, Academic Press, pp 439-446

Barron MG, Vivian DN, Heintz RA, Yim UH (2020) Long-term ecological impacts from oil spills: comparison of Exxon Valdez, Hebei spirit, and deepwater horizon. Environ Sci Technol 54(11):6456-6467. https://doi.org/10.1021/acs.est.9b05020

Basumatary B, Bordoloi S, Sarma HP (2012) Crude oil-contaminated soil phytoremediation by using Cyperus brevifolius (Rottb) Hassk. Water Air Soil Poll 223(6):3373-3383

Baudouy S, Legorjus C (1991) Sendji field-people's Republic of Congo, Congo Basin. In: Foster NH, Beaumont EA (eds) Treatise of petroleum geology, Atlas of oil and gas fields-Structural traps V. Tulsa, American Association of Petroleum Geologists, pp 121-149

Bebeteidoh OL, Komesta S, Pazouki K, Norman R (2020) Sustained impact of the activities of local crude oil refiners on their host communities in Nigeria. Heliyon. https://doi.org/10.1016/j.heliy on.2020.e04000

Beyer J, Goksøyr A, Hjermann DØ, Klungsøyr J (2020) Environmental effects of offshore produced water discharges: a review focused on the Norwegian continental shelf. Mar Environ Res. https:// doi.org/10.1016/j.marenvres.2020.105155

Binazadeh M, Li Z, Karimi IA (2020) Optimization of biodegradation of long chain n-Alkanes by Rhodococcus sp. Moj-3449 using response surface methodology. Phys Chem Res 8(1):45-59. https://doi.org/10.22036/pcr.2019.204077.1682

Blake G (1969) Oil production in Libya. Geography, 54(2), 221-223. Retrieved May 312021 from http://www.jstor.org/stable/40566 791

Boele R, Fabig H, Wheeler D (2001) Shell, Nigeria and the Ogoni. A study in unsustainable development: I the story of shell, Nigeria and the Ogoni people-environment, economy, relationships: conflict and prospects for resolution 1. Sustain Develop 9(2):74-86

Brette F, Shiels HA, Galli GL, Cros C, Incardona JP, Scholz NL, Block BA (2017) A novel cardiotoxic mechanism for a pervasive global pollutant. Sci Rep 7(1):1-9 
Briggs D (2003) Environmental pollution and the global burden of disease. Br Med Bull 68(1):1-24. https://doi.org/10.1093/bmb/ $\operatorname{ldg} 019$

Briggs KT, Yoshida SH, Gershwin ME (1996) The influence of petrochemicals and stress on the immune system of seabirds. Regul Toxicol Pharmacol 23(2):145-155

Brown I, Tari E ( 2015) An evaluation of the effects of petroleum exploration and production activities on the social environment in ogoni land, Nigeria. Int J Sci Technol Res

Brownfield ME, Charpentier RR (2006) Geology and total petroleum systems of the Gulf of Guinea Province of west Africa. US Geol Survey Bull 2207:32

Bustin RM (1988) Sedimentology and characteristics of dispersed organic matter in Tertiary Niger Delta: origin of sorce rocks in a deltaic environment. AAPG Bull 72:277-298

Carpenter PJ, Higuera-Diaz IC, Thompson MD, Atre S, Mandell W (2003) Accuracy of seismic refraction tomography codes at karst sites, geophysical site characterization: seeing beneath the surface. Proceedings of a symposium on the application of geophysics to engineering and environmental problems, San Antonio, pp 832-840.

Cerqueda-García D, Améndola-Pimenta M, Zamora-Briseño JA, González-Penagos CE, Árcega-Cabrera F, Ceja-Moreno V, Rodríguez-Canul R (2020) Effects of chronic exposure to water accommodated fraction (WAF) of light crude oil on gut microbiota composition of the lined sole (Achirus lineatus). Mar Environ Res. https://doi.org/10.1016/j.marenvres.2020.105116

Cheremisinoff NP, Rosenfeld PE (2009) Handbook of pollution prevention and cleaner production, vol. 1. Best practices in the petroleum industry, William Andrew

Chijioke B, Ebong IB, Ufomba H (2018) The Impact of oil exploration and environmental degradation in the Niger Delta region of Nigeria: a study of oil producing communities in Akwa Ibom state. Glob J Hum Soc Sci Polit Sci 18:55-70

Clark D (2014) Methods for determining remanent and total magnetizations of magnetic sources-a review. Explor Geophys 45(4):271-304

Collins CD (2007) Methods in biotechnology implementing phytoremediation of petroleum hydrocarbons phytoremediation. Humana Press, Totowa. https://doi.org/10.1007/978-1-59745-098-0_8

Cramer BJ, Hiltunen DR (2004) Investigation of bridge foundation sites in karst terrane via seismic refraction tomography 83rd annual meeting compendium of papers CD-ROM. Transportation Research Board, Washington

Dahl J, Moldowan JM, Teerman SC, McCaffrey MA, Sundararaman P, Stelting CE (1994) Source rock quality determination from oil biomarkers; a new geochemical technique. Assoc Petroleum Geol Bull 78:1507-1528

Darkwah WK, Bismark O, Maxwell A, Desmond KA, Danso KB, Oti-Mensah EA, Quachie AT, Adormaa BB (2018) Greenhouse effect: greenhouse gases and their impact on global warming. J Sci Res Reports 17(6):1-9. https://doi.org/10.9734/JSRR/ 2017/39630

Date AW (2011) Analytic combustion: with thermodynamics, chemical kinetics and mass transfer. Cambridge University Press. Accessed 4 Dec 2020

Dauda RS (2017) Poverty and economic growth in Nigeria: Issues and policies. J Poverty 21(1):61-79

De Anna JS, Castro JM, Darraz LA, Elías FD, Cárcamo JG, Luquet CM (2021) Exposure to hydrocarbons and chlorpyrifos alters the expression of nuclear receptors and antioxidant, detoxifying, and immune response proteins in the liver of the rainbow trout Oncorhynchus Mykiss. Ecotoxicol Environ Saf. https:// doi.org/10.1016/j.ecoenv.2020.111394

Deivakumari M, Sanjivkumar M, Suganya AM, Prabakaran JR, Palavesam A, Immanuel G (2020) Studies on reclamation of crude oil polluted soil by biosurfactant producing Pseudomonas aeruginosa (DKB1). Biocatal Agric Biotechnol. https://doi.org/10. 1016/j.bcab.2020.101773

Demirel Y (2012) Energy: production, conversion, storage, conservation, and coupling. Springer Science and Business Media, Berlin

Devold H (2013) Oil and gas production handbook: an introduction to oil and gas production, transport, refining and petrochemical industry. ABB oil and gas, Oslo, p 162

Dincer I, Rosen MA (2013) Exergy analysis of crude oil distillation systems. Exergy. https://doi.org/10.1016/b978-0-08-097089-9. 00016-4

Dong ZL, Wang BS, Li J (2020) Effects of petroleum hydrocarbon contamination on soil bacterial diversity in the permafrost region of the Qinghai-Tibetan Plateau. Soil Sedim Contam 29(3):322-339. https://doi.org/10.1080/15320383.2019.17101 09

Donwa PA, Mgbame CO, Ogbeide OL (2015) Corruption in the Nigerian oil and gas industry and implication for economic growth. Int J African Asian Stud 14:29-41

Dubansky B, Verbeck G, Mach P, Burggren W (2018) Methodology for exposing avian embryos to quantified levels of airborne aromatic compounds associated with crude oil spills. Environ Toxicol Pharmacol 58:163-169

Duissenov D (2013) Production and processing of sour crude and natural gas - challenges due to increasing stringent regulations. Dissertation submitted to NTNU-Trondheim, Norwegian University of Science and Technology

Echikh K (1998) Geology and hydrocarbon occurrences in the Ghadames Basin, Algeria, Tunisia, Libya. Geological Society, London, Special Publications, pp 109-129. https://doi.org/10.1144/ GSL.SP.1998.132.01.06

Economides MJ, Nikolaou M (2011) Technologies for oil and gas production: present and future. AIChE J 57(8):1974-1982. https:// doi.org/10.1002/aic.12714

ECOWAS-SWAC/OECD, 2007. Atlas on regional integration in West Africa: Economic series, p 20

Ehirim NC, Praise NC, Osuji EE, Onyemauwa SC (2018) Economics of adoption of environmentally sustainable fishing techniques in coastal mangrove Niger delta Nigeria. Arch Bus Res 6(5):65-80

Ekperusi AO, Nwachukwu EO, Sikoki FD (2020) Assessing and modelling the efficacy of lemna paucicostata for the phytoremediation of petroleum hydrocarbons in crude oil-contaminated wetlands. Sci Reports. https://doi.org/10.1038/s41598-020-65389-z

Ekweozor CM (2004) Source rocks of giant hydrocarbon deposits in deep offshore, Niger Delta. Abstracts of Nigerian Association of petroleum explorationists and American Association of petroleum geologists bulletin West Africa deep-water regional conference, Abuja, Nigeria

EL-Sharif, IAA (2005) An empirical investigation of the impact of oil price changes in disparate economic systems: evidence from the UK and Libya. PhD thesis. Dundee University

El-Shimy Y (2016) Cheap oil is hurting Egypt's economy in the short term and could have wider political consequences. Cairo's crude crises. Carnegie endowment for international peace. https://carnegieendowment.org/sada/63178

Energy Information Administration (2017) Gasoline-a petroleum product. https://www.eia.gov/energyexplained/gasoline/. Archived from the original on 24 May 2017. Accessed 4 Dec 2020

England GL, Rasmussen B, Krapez B, Groves DI (2002) Archaean oil migration in the Witwatersrand Basin of South Africa. J Geol Soc Lond 159:189-220

Enibukun JM, Boboye BE (2020) Molecular characterization and evaluation of crude oil remediation potential of some rhizobia 
isolated from plant root nodules. Nova Biotechnol Et Chimica 19(1):80-88. https://doi.org/10.36547/nbc.v19i1.580

Esler D, Schmutz A, Jarvis L, Mulcahy D (2000) Winter survival of adult female harlequin ducks in relation to history of contamination by the Exxon Valdez oil spill, p 28

Fallon JA, Smith EP, Schoch N, Paruk JD, Adams EA, Evers DC, Hopkins WA (2018) Hematological indices of injury to lightly oiled birds from the Deepwater Horizon oil spill. Environ Toxicol Chem 37(2):451-461

Fallon JA, Smith EP, Schoch N, Paruk JD, Adams EM, Evers DC, Hopkins WA (2020) Ultraviolet-assisted oiling assessment improves detection of oiled birds experiencing clinical signs of hemolytic anemia after exposure to the Deepwater Horizon oil spill. Ecotoxicology 29(9):1399-1408. https://doi.org/10. 1007/s10646-020-02255-8

Faria J (2020) Main oil producing countries in Africa 2019. Retrieved 11 Dec from https://www.statista.com/statistics/ 1178514/main-oil-producing-countries-in-africa

Fentiman A, Zabbey N (2015) Environmental degradation and cultural erosion in Ogoniland: a case study of the oil spills in Bodo. Extrac Indus Soc 2(4):615-624

Friends of the Earth (FOE) (2004) Media briefing, gas flaring in Nigeria. p 1-2. Available from: www.foe.co.uk/resource/ media_briefing/gasflaringinnigeria.pdf

Funnell M (2016) Five most common drilling methods used in oil and gas exploration. Retrieved from the driller.com/articles

Gao D (2011) Latest developments in seismic texture analysis for subsurface structure, facies, and reservoir characterization: a review. Geophysics 76(2):W1-W13

Garcia SM, Du Clos KT, Hawkins OH, Gemmell BJ (2020) Sublethal effects of crude oil and chemical dispersants on multiple life history stages of the eastern oyster, crassostrea virginica. J Marine Sci Eng 8(10):1-14. https://doi.org/10.3390/jmse8 100808

Giese M, Goldsworthy SD, Gales R, Brothers N, Hamill J (2000) Effects of the Iron Baron oil spill on little penguins (Eudyptula minor). III. Breeding success of rehabilitated oiled birds. Wildlife Res 27(6):583-591

Giwa SO, Nwaokocha CN, Kuye SI, Adama KO (2019) Gas flaring attendant impacts of criteria and particulate pollutants: a case of Niger Delta region of Nigeria. J King Saud Univ Eng Sci 31:209-217

Goethe F (1968) The effects of oil pollution on populations of marine and coastal birds. Helgoländer Meeresun 17(1):370-374

Golet GH, Seiser PE, McGuire AD, Roby DD, Fischer JB, Kuletz KJ, Newman SH (2002) Long-term direct and indirect effects of the 'Exxon Valdez' oil spill on pigeon guillemots in Prince William Sound, Alaska. Mar Ecol Prog Ser 241:287-304

Gong C, Lao J, Wang B, Li X, Li G, Gao J, Luo J (2020) Fast and allweather cleanup of viscous crude-oil spills with $\mathrm{Ti}_{3} \mathrm{C}_{2} \mathrm{TX}$ MXene wrapped sponge. J Mater Chem A 8(38):20162-20167. https:// doi.org/10.1039/D0TA06480G

Graham E, Ovadia JS (2019) Oil exploration and production in SubSaharan Africa, 1990-present: trends and developments. Extr Indus Soc. https://doi.org/10.1016/j.exis.2019.02.001

Gurung S, Dubansky B, Virgen CA, Verbeck GF, Murphy DW (2021) Effects of crude oil vapors on the cardiovascular flow of embryonic Gulf killifish. Sci Total Environ. https://doi.org/10.1016/j. scitotenv.2020.141627

Haack RC, Sundararaman P, Diedjomahor JO, Xiao H, Gant NJ, May ED, Kelsch K (2000) Niger delta petroleum systems, Nigeria. In: Mello MR, Katz BJ (eds) Petroleum systems of South Atlantic margins. American Association of Petroleum Geologists, USA, pp 213-231
Hachay SGO (2017) Oil and gas exploration: methods and application. American Geophysical Union, Florida, Washington DC, and John Wiley \& Sons, Inc., Hoboken, New Jersey, p 288

Hewelke E, Szatyłowicz J, Hewelke P, Gnatowski T, Aghalarov R (2018) The impact of diesel oil pollution on the hydrophobicity and CO2 efflux of forest soils. Water Air Soil Pollut 229(2):51

Hilchie DW (1978) Applied openhole log interpretation (for geologists and engineers), p 350

Hilchie DW (1982) Applied openhole log interpretation for geologists and petroleum engineers, $\mathrm{p} 400$

Hiltunen DR, Cramer BJ (2006) Geophysical characterization of bridge foundation sites in karst terrane. 85th Annual Meeting Compendium of Papers CD-ROM, Transportation Research Board, Washington DC

Honório BCZ, Drummond RD, Alexandre CV, Alexandre CS, Emilson PL (2012) Well log denoising and geological enhancement based on discrete wavelet transform and hybrid thresholding. Energy Explor Exploit 30(3):417-433

Hope KR (2017) Corruption in Nigeria. Corruption and governance in Africa. Palgrave Macmillan, London, pp 125-162

Issoufi I, Rhykerd R, Smiciklas K (2006) Seedling growth of agronomic crops in crude oil contaminated soil. J Agron Crop Sci 192(4):310-317

Iyer RR, Grossmann IE, Vasantharajan S, Cullick AS (1998) Optimal planning and scheduling of offshore oil field infrastructure investment and operations. Ind Eng Chem Res 37(4):1380-1397

Jiang D, Chen L, Xia N et al (2020) (2020) Elevated atmospheric CO2 impact on carbon and nitrogen transformations and microbial community in replicated wetland. Ecol Processes 9:57

Junger S (2007) Blood oil. http://www.vanityfair.com/politics/features/ 2007/02/junger200702. Accessed 2 Dec 2020

Kalu K, Ott K (2019) Ethical issues in environmental pollution: multinational corporations (MNCs) and oil industries in tropical regions-the Nigerian niger-delta case. In: Chemhuru M. (eds) African environmental ethics. The international library of environmental, agricultural and food ethics, Springer, Cham. https:// doi.org/10.1007/978-3-030-18807-8_18

Kamgar A, Hassanajili S, Unbehaun H (2020) Oil spill remediation from water surface using induction of magnetorheological behavior in oil by functionalized sawdust. Chem Eng Res Des 160:119-128. https://doi.org/10.1016/j.cherd.2020.05.024

Kang CU, Kim DH, Khan MA, Kumar R, Ji SE, Choi KW, Jeon BH (2020) Pyrolytic remediation ofcrude oil-contaminated soil. Sci Total Environ. https://doi.org/10.1016/j.scitotenv.2020.136498

Karolyté R, Johnson G, Yielding G, Gilfillan SMV (2020) Fault Seal modeling - the influence of fluid properties on fault sealing capacity in hydrocarbon and $\mathrm{CO}_{2}$ systems. Pet Geosci. https:// doi.org/10.1144/petgeo2019-126

Kearey P, Brooks M, Ian H (2002) An Introduction to geophysical exploration. Blackwell Science Ltd, London, p 281

Kelishadi R (2012) Environmental pollution: health effects and operational implications for pollutanats removal. J Environ Public Health

Kessler R (2013) Sunset for leaded aviation gasoline. Environ Health Perspect 121(2):a54-a57. https://doi.org/10.1289/ehp.121-a54

Khanpour-Alikelayeh E, Partovinia A, Talebi A, Kermanian H (2020) Investigation of Bacillus licheniformis in the biodegradation of Iranian heavy crude oil: a two-stage sequential approach containing factor-screening and optimization. Ecotoxicol Environ Saf. https://doi.org/10.1016/j.ecoenv.2020.111103

Kholghi N, Amani H, Malekmahmoodi S, Amiri A (2020) Investigation on heavy metal removal from a crude oil contaminated soil using rhamnolipid biosurfactant as a new eco-friendly method. Tenside Surf Deterg 57(6):515-520. https://doi.org/10.3139/113.110710

Khursigara AJ, Johansen JL, Esbaugh AJ (2021) The effects of acute crude oil exposure on growth and competition in red drum, 
Sciaenops ocellatus. Sci Total Environ. https://doi.org/10.1016/j. scitotenv.2020.141804

Kiamarsi Z, Kafi M, Soleimani M, Nezami A, Lutts S (2020) Conjunction of Vetiveria zizanioides L. and oil-degrading bacteria as a promising technique for remediation of crude oil-contaminated soils. J Clean Prod. https://doi.org/10.1016/j.jclepro.2019.119719

King MS (2009) Recent developments in seismic rock physics. Int J Rock Mech Mining Sci 46(8):1341-1348

Kister HZ (1992) Distillation Design (1st ed). McGraw-Hill

Knothe G, Sharp CA, Ryan TW (2006) Exhaust emissions of biodiesel, petrodiesel, neat methyl esters, and alkanes in a new technology engine. Energy Fuels 20(1):403-408

Kramer R (2010) Liberia: government signs up Chevron as oil exploration partner. Accessed 2 Dec 2020

Kuch SG, Bavumiragira JP (2019) Impact of crude oil exploration and production and its implication on human health: South Sudan review. Int J Sci Res Publ 9(4):8836

Kyomugasho M (2016) Oil industry in Uganda: the socio-economic effects on the people of Kabaale Village, Hoima, and Bunyoro region in Uganda. Dissertations-ALL. 613. https://surface.syr. edu/etd/613

Ławniczak Ł, Woźniak-Karczewska M, Loibner AP, Heipieper HJ, Chrzanowski $€$ (2020) Microbial degradation of hydrocarbonsbasic principles for bioremediation: a review. Molecules. https:// doi.org/10.3390/molecules25040856

Li D-C, Xu W-F, Mu Y, Yu H-Q, Jiang H, Crittenden JC (2018) Remediation of petroleum-contaminated soil and simultaneous recovery of oil by fast pyrolysis. Environ Sci Technol 52(9):53305338. https://doi.org/10.1021/acs.est.7b03899

Li H, Li Y, Bao M, Li S (2021) Solid inoculants as a practice for bioaugmentation to enhance bioremediation of hydrocarbon contaminated areas. Chemosphere. https://doi.org/10.1016/j.chemo sphere.2020.128175

Li Q, Yang G, Wang K, Wang X (2020) Preparation of carbondoped alumina beads and their application as the supports of $\mathrm{Pt}-\mathrm{Sn}-\mathrm{K}$ catalysts for the dehydrogenation of propane. React Kinet Mechan Catal

Lunde G, Aubert K, Lauritzen O, Lorange E (1992) Tertiary uplift of the Kwanza basin in Angola. In: Curnelle R (ed) Géologie Africaine, 1 er Colloque de Stratigraphie et de Paléogéographie des Bassins Sédimentaires Ouest-Africains, 2 e Colloque Africain de Micropaléontologie, Libreville, Gabon, Recueil des Communications: Boussens, Elf Aquitaine, pp 99-117

Lüning S, Adamson K, Craig J 2003 Frasnian organic-rich shales in North Africa: regional distribution and depositional model. vol 207. Geological Society, London, Special Publications, p 165. https://doi.org/10.1144/GSL.SP.2003.207.9

Maamar A, Lucchesi ME, Debaets S, van Long NN, Quemener M, Coton E, Matallah-Boutiba A (2020) Highlighting the crude oil bioremediation potential of marine fungi isolated from the Port of Oran (Algeria). Diversity. https://doi.org/10.3390/ D12050196

Magnuson JT, Bautista NM, Lucero J, Lund AK, Xu EG, Schlenk D, Roberts AP (2020) Exposure to crude oil induces retinal apoptosis and impairs visual function in fish. Environ Sci Technol 54(5):2843-2850

Malaquias A (2001) Making war and lots of money: the political economy of protracted conflict in Angola. Rev Afr Political Eco 28(90): 521-536. Retrieved May 31 2021, from http://www.jstor. org/stable/4006834

Marinescu M, Toti M, Tanase V, Plopeanu G, Calciu I, Marinescu M (2011) The effects of crude oil pollution on physical and chemical characteristics of soil. Res J Agric Sci 43(3):125-129

Matemilola S, Adedeji OH, Enoguanbhor EC (2018) Land use/land cover change in petroleum-producing regions of Nigeria. In: The political ecology of oil and gas activities in the Nigerian aquatic ecosystem. Academic Press, pp 257-276

McKenzie LM, Allshouse W, Daniels S (2019) Congenital heart defects and intensity of oil and gas well site activities in early pregnancy. Environ Int 132:104949

Mehadi Z (1990) Sedimentology of the Sbaa oil reservoir in the Timimoun basin (S. Algeria). United States, 1990. Annual convention and exposition of the American Association of Petroleum Geologists, vol 74. San Francisco, CA, p 5

Mensah J, Casadevall SR (2019) Sustainable development: Meaning, history, principles, pillars, and implications for human action: literature review. Cogent Social Sci 5:1. https://doi.org/10.1080/ 23311886.2019.1653531

Miroslav K (2011) Geophysical well logging. In: Harsh KG (ed) Encyclopedia of solid earth geophysics. Springer, Berlin

Mohammed M (2018) Oil production and economic growth in Angola. Int J Energy Econ Policy 8(2):127-131

Moorthy B, Chu C, Carlin DJ (2015) Polycyclic aromatic hydrocarbons: from metabolism to lung cancer. Toxicol Sci 145(1):5-15

Muangchinda C, Srisuwankarn P, Boubpha S, Chavanich S, Pinyakong O (2020) The effect of bioaugmentation with Exiguobacterium sp. AO-11 on crude oil removal and the bacterial community in sediment microcosms, and the development of a liquid readyto-use inoculum. Chemosphere. https://doi.org/10.1016/j.chemo sphere.2020.126303

Mugisa S (2016) Socio-economic effects of oil exploration among Hoima municipality communities, Uganda. A dissertation submitted for a degree in executive master of business administration at the school of business and management, UTAMU pp 1-107

Murray TA, Power WL (2020) Discussion on fault seal modelling - the influence of fluid properties on fault sealing capacity in hydrocarbon and $\mathrm{CO}_{2}$ systems. Pet Geosci 26:607-609. https://doi.org/ 10.1144/petgeo2020-061

Nestvold EO (1993) 3D Seismic technology_impact on exploration and production. AAPG Bull Am Assoc Petr Geol 77(2):338-338

Nguah JA, Mensah PK (2016) The emerging oil industry in Ghana: socioeconomic impact on the people of the fishing communities in Western Region. Int J Petroleum Gas Explor Manage 2(1): $1-25$

Nyemah RGM (2011) Economics of oil discovery in West Africa: the Nigerian experience regional maritime University Journal. Publication of Regional Maritime University, Accra, pp 47-49

Ofwona C (2010) Introduction to geophysical well logging and flow testing. Presented at short course V on exploration for geothermal resources, Kenya, p 6

Ogbe OB (2020) Sequence stratigraphic controls on reservoir characterization and architectural analysis: a case study of Tovo field, coastal swamp depobelt, Niger Delta Basin Nigeria. Marine Petroleum Geol 121:104579

Olajuyigbe FM, Adeleye OA, Kolawole AO, Bolarinwa TO, Fasakin EA, Asenuga ER, Ajele JO (2020) Bioremediation treatment improves water quality for Nile tilapia (Oreochromis niloticus) under crude oil pollution. Environ Sci Pollut Res 27(20):2568925702. https://doi.org/10.1007/s11356-020-09020-8

Olujimi JAB, Emmanuel AA, Sogbon O (2011) Environmental implications of oil exploration and exploitation in the coastal region of Ondo State, Nigeria: a regional planning appraisal. J Geo Regional Plan 4(3):110-121

Oluwajana OA (2018) Hydrocarbon potential of late miocene to early pliocene source rocks of shallow offshore, Niger Delta Basin, Nigeria. Pac J Sci Technol 19(2):399-409

Oluwajana (2018) Maturity modelling and source rock evaluation of upper oligocene source rocks (within agbada formation), greater Ughelli depobelt Niger Delta Basin. Petroleum Coal 60(2):168-179 
Oluwajana OA (2019) 2D seismic interpretation and evaluation of middle miocene source rocks within Agbada formation, coastal swamp depobelt, Niger Delta basin. Nigeria Global J Geol Sci 17(1):97-103

Oluwajana OA, Ehinola OA, Adegoke CG (2017) Modeling hydrocarbon generation potentials of Eocene source rocks in the Agbada formation, northern delta depobelt, niger delta basin, nigeria. $\mathrm{J}$ Petroleum Explor Prod Technol 7:379-388. https://doi.org/10. 1007/s13202-016-0286-y

Onuegbulam MC (2018) Restorative justice intervention in the repression of crime in oil and gas production in Nigeria. Nnamdi Azikiwe Univ J Int Law Jurisprud 9(2):167-176

Onyena AP, Sam K (2020) A review of the threat of oil exploitation to mangrove ecosystem: insights from Niger Delta Nigeria. Global Ecol Conserv 22:00961

Ordinioha B, Brisibe S (2013) The human health implications of crude oil spills in the Niger delta, Nigeria: An interpretation of published studies. Niger Med J 54(1):10-16. https://doi.org/10.4103/ 0300-1652.108887

Ore OT, Adeola AO (2021) Toxic metals in oil sands: review of human health implications, environmental impact and potential remediation using membrane-based approach. Energy Ecol Environ 6:81-91. https://doi.org/10.1007/s40974-020-00196-w

Orozco JC, Shuaib DT, Marshall CL, Khan MI (2020) Divanadium substituted keggin $\left[\mathrm{PV}_{2} \mathrm{~W}_{10} \mathrm{O}_{40}\right]$ on non-reducible supports$\mathrm{Al}_{2} \mathrm{O}_{3}$ and $\mathrm{SiO}_{2}$ : synthesis, characterization, and catalytic properties for oxidative dehydrogenation of propane. React Kinet Mechan Catal

Otitoloju A, Dan-Patrick J (2010) Effects of gas flaring on blood parameters and respiratory system of laboratory mice, Mus musculus. Environmentalist 30:340-346. https://doi.org/10.1007/ s10669-010-9288-3

Parasnis DS (1993) Principles of applied geophysics. Chapman and Hall, London, p 429

Parker J, Bertelli L, Dromgoole P (2003) Special issue on 4D seismic technology. Petroleum Geosci 9(4):4. https://doi.org/10.1144/ 1354-079302-for

Pasley MA, Wilson EN, Abreu VA, Brandão MGP, Telles AS (1998) Lower cretaceous stratigraphy and source rock distribution in pre-salt basins of the South Atlantic-comparison of Angola and southern Brazil. In: Mello MR, Yilmaz PO (eds) Rio 98petroleum geology in a changing world, 1998. Rio de Janeiro, Brazil, extended abstracts volume, p 822-823

Pathak C, Mandalia HC (2012) Petroleum industries: environmental pollution effects, management and treatment methods. Int J Sep Environ Sci 1(1):2163-3851

Paulauskiene T, Uebe J, Karasu AU, Anne O (2020) Investigation of cellulose-based aerogels for oil spill removal. Water Air Soil Pollut. https://doi.org/10.1007/s11270-020-04799-1

Peng S, Zhou Q, Cai Z, Zhang Z (2009) Phytoremediation of petroleum contaminated soils by Mirabilis Jalapa L. in a greenhouse plot experiment. J Hazard Mater 168(2-3):1490-1496

Pickett GR (1970) Applications for borehole geophysics in geophysical exploration. Geophysics 35:81-92

Pittock J, Baumgartner L, Finlayson CM, Thiem JD, Forbes J, Silva LG, Arthington AH (2018) Managing threats to freshwater systems within protected areas. Freshwater ecosystems in protected areas: conservation and management, pp 84-109.

Quigley PT (2006) Ground proving seismic refraction tomography (SRT) in laterally variable karstic limestone terrain. M. Eng. Thesis. The University of Florida, p 143

Ramos DT, Maranho LT, Godoi AFL, da Silva CarvalhoFilho MA, Lacerda LG, de Vasconcelos EC (2009) Petroleum hydrocarbons rhizodegradation by Sebastiania commersoniana (BAILL) LB SM \& Downs. Water Air Soil Pollution Focus 9(3-4):293-302
Raposo A, Inkollu M (1998) Tertiary reservoirs in Congo-KwanzaNamibe Basins. In: Mello MR, Yilmaz PO (eds) Rio 98-Petroleum geology in a changing world, 1998. Rio de Janeiro, Brazil, extended abstracts volume, $\mathrm{p}$ 668-669

Rodrigues EM, Cesar DE, Santos de Oliveira R, de Paula Siqueira T, Tótola MR (2020) Hydrocarbonoclastic bacterial species growing on hexadecane: implications for bioaugmentation in marine ecosystems. Environ Pollut. https://doi.org/10.1016/j.envpol. 2020.115579

Sam K, Zabbey N (2018) Contaminated land and wetland remediation in Nigeria: opportunities for sustainable livelihood creation. Sci Total Environ 639:1560-1573

Sam K, Coulon F, Prpich G (2017) Management of petroleum hydrocarbon contaminated sites in Nigeria: current challenges and future direction. Land Use Policy 64:133-144

Saputelli L, Nikolaou M, Economides MJ (2005) Self-learning reservoir management. SPE Reservoir Eval Eng 8(6):534-547. https:// doi.org/10.2118/84064-PA

Schlumberger (1972) Log interpretation manual/principles. Schlumberger Well Series Inc, Ridgefield

Schlumberger (1974) Log interpretation manual/applications. Schlumberger Well Series Inc, Ridgefield

Schlumberger (1977) Log interpretation/charts. Schlumberger Well Series Inc, Houston

Schlumberger (1979) Log interpretation/charts. Schlumberger Well Series Inc, Houston

Schoellkopf NB, Patterson BA (2000) Petroleum systems of offshore Cabinda, Angola. In: Mello MR, Katz BJ (eds) Petroleum systems of South Atlantic margins: American Association of Petroleum Geologists Memoir, vol 73, p 361-376.

Selley RC, van der Spuy D (2016) The oil and gas basins of Africa. Int Union Geol Sci 39(2):429

Shahmirzaee M, Hemmati-Sarapardeh A, Husein MM, Schaffie M, Ranjbar M (2020) Development of a powerful zeolitic imidazolate framework (ZIF-8)/carbon fiber nanocomposite for separation of hydrocarbons and crude oil from wastewater. Microporous Mesoporous Mater. https://doi.org/10.1016/j.micromeso.2020. 110463

Sharma A, Chaturvedi D (2014) Geochemical methods of petroleum exploration. Int J Sci Eng Res 5(5):108-112

Sheriff RE (1991) encyclopedic dictionary of exploration geophysics. Society of Exploration Geophysicists, Tulsa, Oklahoma, p 376

Sojinu SO, Ejeromedoghene O (2019) Environmental challenges associated with processing of heavy crude oils, processing of heavy crude oils-challenges and opportunities Ramasamy Marappa Gounder. IntechOpen. https://doi.org/10.5772/intechopen.82605

Soliman EM, Ahmed SA, Fadl AA (2020) Adsorptive removal of oil spill from sea water surface using magnetic wood sawdust as a novel nano-composite synthesized via microwave approach 03 Chemical Sciences 0306 Physical Chemistry. J Environ Health Sci Eng 18(1):79-90. https://doi.org/10.1007/ s40201-019-00440-4

Stenehjem JS, Kjærheim K, Bråtveit M, Samuelsen SO, Barone-Adesi F, Rothman N, Grimsrud TK (2015) Benzene exposure and risk of lymphohaematopoietic cancers in 25000 offshore oil industry workers. Br J Cancer 112(9):1603-1612

Steyn P (2009) Oil exploration in colonial Nigeria, c. 1903-58. J Imperial Commonwealth History 37(2):249-274. https://doi.org/10. 1080/03086530903010376

Strelitz J, Keil AP, Richardson DB, Heiss G, Gammon MD, Kwok RK, Engel LS (2019) Self-reported myocardial infarction and fatal coronary heart disease among oil spill workers and community members 5 years after Deepwater horizon. Environ Res 168:70-79

Tantua B, Kamruzzaman P (2016) Revisiting militancy: examining niger delta. Review of African Political Economy 1(2):1-13 
Telford WM, Geldart LP, Sheriff RE, Keys DA (1990) Applied geophysics. Cambridge University Press. https://doi.org/10.1017/ CBO9781139167932

Traut MW, Boote DRD, Clack-Lowes DD (1998) Exploration history of the Palaeozoic petroleum systems of North Africa. In: Macgregor DS, Moody RZJ, Clark-Lowes DD (eds) Petroleum geology of North Africa. Geological Society Special Publication, London, pp 69-78

Tsvankin I, Gaiser J, Grechka V, van der Baan M, Thomsen L (2010) Seismic anisotropy in exploration and reservoir characterization: an overview. Geophysics 75(5):A15-A29

Underdown R, Redfern J (2008) Petroleum generation and migration in the Ghadames Basin, North Africa: A two-dimensional basinmodeling study. AAPG Bull 92(1):53-76

UNEP (United Nations Environmental Programme) (1997) Environmental management in oil and gas exploration and production: an overview of issues and management approaches. UNEP IE/ PAC Technical Report 37:76

Vargas GC, Au WW, Izzotti A (2020) Public health issues from crudeoil production in the Ecuadorian Amazon territories. Sci Total Environ 719:134647

Vasilyeva G, Kondrashina V, Strijakova E, Ortega-Calvo JJ (2020) Adsorptive bioremediation of soil highly contaminated with crude oil. Sci Total Environ. https://doi.org/10.1016/j.scitotenv. 2019.135739

Verâne J, dos Santos NCP, da Silva VL, de Almeida M, de Oliveira OMC, Moreira ÍTA (2020) Phytoremediation of polycyclic aromatic hydrocarbons (PAHs) in mangrove sediments using Rhizophora mangle. Mar Pollut Bull. https://doi.org/10.1016/j.marpo lbul.2020.111687
Wang X, Peng G, Chen M, Zhao M, He Y, Jiang Y, Lin S (2020) Reduced graphene oxide composites and its real-life application potential for in-situ crude oil removal. Chemosphere. https://doi. org/10.1016/j.chemosphere.2020.126141

Wei Z, Wang JJ, Gaston LA, Li J, Fultz LM, DeLaune RD, Dodla SK (2020a) Remediation of crude oil-contaminated coastal marsh soil: Integrated effect of biochar, rhamnolipid biosurfactant and nitrogen application. J Hazard Mater. https://doi.org/10.1016/j. jhazmat.2020.122595

Wei Z, Wang JJ, Meng Y, Li J, Gaston LA, Fultz LM, DeLaune RD (2020b) Potential use of biochar and rhamnolipid biosurfactant for remediation of crude oil-contaminated coastal wetland soil: ecotoxicity assessment. Chemosphere. https://doi.org/10.1016/j. chemosphere.2020.126617

Weimer P, Davis TL (1996) Applications of 3-D seismic data to exploration and production. AAPG Studies in Geology, Tulsa, OK

Wong CY, Tan IS, Foo HCY, Tang DKH, Tan YH, Yeong YF, Lam MK (2020) Monolayer grafting of APTES modified graphene oxide on silica coated magnetite: Synthesis, characterization and application in heavy oil removal. Paper presented at the IOP Conference Series: Materials Science and Engineering, vol 943, p 012023.

World Bank (2017) World bank world development indicators. World Bank, Washington

Yamato O, Goto I, Maede Y (1996) Hemolytic anemia in wild seaducks caused by marine oil pollution. J Wildl Dis 32(2):381-384

Zhao Y, Chen W, Wen D (2020) The effects of crude oil on microbial nitrogen cycling in coastal sediments. Environ Int. https://doi. org/10.1016/j.envint.2020.105724 